\title{
Adult Motor Neuron Apoptosis Is Mediated by Nitric Oxide and Fas Death Receptor Linked by DNA Damage and p53 Activation
}

\author{
Lee J. Martin, ${ }^{1,2}$ Kevin Chen, ${ }^{1}$ and Zhiping Liu ${ }^{1}$ \\ ${ }^{1}$ Department of Pathology, Division of Neuropathology, and 2Department of Neuroscience, Johns Hopkins University School of Medicine, Baltimore, \\ Maryland 21205-2196
}

\begin{abstract}
The mechanisms of injury- and disease-related degeneration of motor neurons (MNs) need clarification. Unilateral avulsion of the sciatic nerve in the mouse induces apoptosis of spinal MNs that is p53 and Bax dependent. We tested the hypothesis that MN apoptosis is Fas death receptor dependent and triggered by nitric oxide (NO)- and superoxide-mediated damage to DNA. MNs in mice lacking functional Fas receptor and Fas ligand were protected from apoptosis. Fas protein levels and cleaved caspase-8 increased in MNs after injury. Fas upregulation was p53 dependent. MNs in mice deficient in neuronal NO synthase (nNOS) and inducible NOS (iNOS) resisted apoptosis. After injury, MNs increased nNOS protein but decreased iNOS protein; however, iNOS contributed more than nNOS to basal and injuryinduced levels of NADPH diaphorase activity in MNs. $\mathrm{NO}$ and peroxynitrite $\left(\mathrm{ONOO}^{-}\right)$fluorescence increased in injured $\mathrm{MNs}$, as did nitrotyrosine staining of MNs. DNA damage, assessed as 8-hydroxy-2-deoxyguanosine and single-stranded DNA, accumulated within injured MNs and was attenuated by nNOS and iNOS deficiency. nNOS deficiency increased DNA repair protein oxoguanine DNAglycosylase, whereas iNOS deficiency blocked diaphorase activity. MN apoptosis was blocked by the antioxidant Trolox and by overexpression of wild-type human superoxide dismutase-1 (SOD1). In contrast, injured MNs in mice harboring mutant human SOD1 had upregulated Fas and iNOS, escalated DNA damage, and accelerated and increased MN degeneration and underwent necrosis instead of apoptosis. Thus, adult spinal MN apoptosis is mediated by upstream NO and $\mathrm{ONOO}^{-}$genotoxicity and downstream p53 and Fas activation and is shifted to necrosis by mutant SOD1.
\end{abstract}

Key words: amyotrophic lateral sclerosis; axotomy; cell death; DNA damage; mutant SOD1; spinal cord injury

\section{Introduction}

Some form of apoptosis may contribute to the pathogenesis of disease in motor neurons (MNs) in people with amyotrophic lateral sclerosis (ALS) (Martin, 1999; Mattson et al., 1999; Sathasivam et al., 2001; Waldmeier, 2003). Apoptosis is an organized form of cell death that eliminates superfluous cells normally during development (Glücksmann, 1951; Oppenheim, 1991), or damaged cells after injury or aberrant replication/repair (Rich et al., 2000), and is mediated by active, intrinsic mechanisms (Danial and Korsmeyer, 2004). MNs in individuals with ALS sustain DNA damage (Ferrante et al., 1997; McClendon and Martin, 2003), and the tumor suppressor protein p53 may participate in the mechanisms of MN apoptosis in ALS (Martin, 2000). Mutations in superoxide dismutase-1 (SOD1) can cause MN disease in some forms of familial ALS (Deng et al., 1993; Rosen et al., 1993); however, $\sim 98 \%$ of ALS patients do not have SOD1 mutations.

Received Nov. 17, 2004; revised May 17, 2005; accepted May 25, 2005.

This work was supported by grants from the United States Public Health Service, the National Institutes of Health, the National Institute of Neurological Disorders and Stroke (NS34100 and NS52098), and the National Institute on Aging (AG16282). The fine technical work of Ann Price and Yan Pan is greatly appreciated.

Correspondence should be addressed to Dr. Lee J. Martin, Department of Pathology, Johns Hopkins University School of Medicine, 558 Ross Building, 720 Rutland Avenue, Baltimore, MD 21205-2196. E-mail: martin|@jhmi.edu. DOI:10.1523/JNEUROSCI.0911-05.2005

Copyright $\odot 2005$ Society for Neuroscience $\quad$ 0270-6474/05/256449-11\$15.00/0
SOD1 has antiapoptotic functions in cultured neurons (Greenlund et al., 1995), and MNs deficient in SOD1 have enhanced vulnerability to axotomy (Reaume et al., 1996). Knowledge of the mechanisms of apoptosis in adult MNs is limited compared with developing MNs. Neurotrophin deprivation has an important role in adult MN death (Wu et al., 2003). A role for nitric oxide $(\mathrm{NO})$ in adult $\mathrm{MN}$ death was recognized by $\mathrm{Wu}$ and colleagues (Wu, 1993; Wu and $\mathrm{Li}, 1993$ ), but the specific contributions of the different isoforms were not examined and still have not been investigated in vivo. Since then, neuronal NO synthase (nNOS) and superoxide anion (Estévez et al., 1998; Estévez and Jordán, 2002) as well as Fas receptor (Raoul et al., 1999) have been implicated in the death of embryonic MNs induced by trophic factor deprivation and zinc-deficient SOD1 (Estévez et al., 1999) in vitro. The formation of peroxynitrite $\left(\mathrm{ONOO}^{-}\right)$in $\mathrm{MNs}$ seems to play a critical role in this $\mathrm{MN}$ death in vitro. Fas can mediate axotomy-induced $\mathrm{MN}$ death in the neonatal brainstem but is not required for developmental programmed cell death of MNs (Ugolini et al., 2003).

We have used an animal injury model of neurodegeneration to further understand the in vivo mechanisms of adult MN apoptosis. Avulsion of the sciatic nerve induces retrograde degeneration lumbar MNs. The MNs die by a process with morphological characteristics of apoptosis (Martin et al., 1999; Martin and Liu, 
2002a). This cell death requires the presence of the Bax and $p 53$ genes, further supporting a role for apoptosis in this neurodegeneration and the possible role of genome instability as a trigger (Martin and Liu, 2002a). Despite this and other (Wu et al., 2003) information, the upstream mechanisms of adult MN apoptosis are not yet clear. In this study, we examined the roles played by the Fas death receptor pathway and the different isoforms of NOS in mediating $\mathrm{MN}$ apoptosis in an adult in vivo model. A more complete understanding of the molecular mechanisms that trigger and regulate $\mathrm{MN}$ apoptosis could be relevant therapeutically to ALS and other disorders of MNs, leading to more selectively targeted drug treatments.

\section{Materials and Methods}

Animals and lesion paradigm of MN apoptosis in vivo. A unilateral sciatic nerve avulsion (SNA) served as the model for producing axotomy and target deprivation of spinal MNs in the rat and mouse. SNA lesions were done on adult (weight, $\sim 150-300 \mathrm{~g}$ ) male Sprague Dawley rats ( $n=100$; Charles River, Wilmington, MA) and on adult (6-8 weeks of age) male

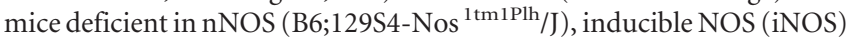
$\left(\mathrm{B} 6 ; 129 \mathrm{P}-\mathrm{Nos} 2^{\text {tmlLau }}\right)$, endothelial NOS (eNOS) (B6;129P2Nos3 $\left.{ }^{\mathrm{tm} 1 \mathrm{Unc}} / \mathrm{J}\right)$, p75 (B6.129S4-Ngfr ${ }^{\mathrm{tm} 1 \mathrm{Jae}} / \mathrm{J}$, congenic), and p53 (B.6129S2-Trp53 ${ }^{\mathrm{tm} 1 \mathrm{Tyj}}$, congenic). Lesions were also done on adult mice with spontaneous mutations in Fas (B6.MRL-Tnfrsf ${ }^{\mathrm{lpr}} / \mathrm{J}$, congenic) and Fas ligand (FasL) (B6Smn.C3-Tnfsf6 ${ }^{\text {gld }} / \mathrm{J}$, congenic), as well as on transgenic $(\mathrm{tg})$ mice expressing the normal allele of the human SOD1 gene (B6SJL-TgN-SOD1 ${ }^{2 \mathrm{Gur}}$ ) and on tg mice expressing human mutant SOD1 (mSOD1) containing the Gly93 $\rightarrow$ Ala substitution (B6SJL-TgNSOD1-G93A $\left.{ }^{1 \text { Gur }}\right)$. Six-week-old tg mSOD1 mice are presymptomatic and do not become symptomatic until $\sim 13$ weeks of age (Gurney et al., 1994). B6129SF2/J mice were controls for $\mathrm{nNOS}^{-1-}$ mice. B6129PF2/J mice were controls for iNOS ${ }^{-1-}$ mice. C57BL/6J mice were controls for $\mathrm{eNOS}^{-1-}$, Fas ${ }^{\mathrm{lpr}}$, FasL ${ }^{\mathrm{gld}}, \mathrm{p} 75^{-/-}$, and $\mathrm{p} 53^{-1-}$ mice. Mice (16-20 per genotype) were purchased from The Jackson Laboratory (Bar Harbor, ME). The Institutional Animal Care and Use Committee approved the animal protocols. The validation and reproducibility of this MN degeneration model in the rat and mouse has been described previously (Martin et al., 1999; Martin and Liu, 2002a).

Cell counting. Wild-type (wt), null, and tg mice were killed at 7, 14, or $21 \mathrm{~d}$ after SNA. Animals were anesthetized with an overdose of sodium pentobarbital and perfused intracardially with ice-cold PBS (100 mM, pH 7.4), followed by ice-cold $4 \%$ paraformaldehyde in PBS. After perfusion fixation, spinal cords remained in situ for $2 \mathrm{~h}$ before they were removed from the vertebral column. After the spinal cords were removed, lumbar enlargements were dissected under a surgical microscope, and L4, L5, L6, and S1 segments were cryoprotected in 20\% glycerol-PBS and frozen under pulverized dry ice. Transverse serial symmetrical sections $(40 \mu \mathrm{m})$ through the spinal cord were cut using a sliding microtome and stored individually in 96-well plates. Sections were selected with a random start and systematically sampled (every ninth section) to generate a subsample of sections from each mouse lumbar spinal cord that were mounted on glass slides and stained with cresyl violet for neuronal counting. Neuronal counts in the ipsilateral and contralateral ventral horns were made at $1000 \times$ magnification using the stereological optical disector method as described previously (Calhoun et al., 1996; Martin et al., 1999). MNs without apoptotic structural changes were counted using strict morphological criteria. These criteria included a round, open, pale nucleus (not condensed and darkly stained), globular Nissl staining of the cytoplasm, and a diameter of $\sim 30-45 \mu \mathrm{m}$. With these criteria, astrocytes, oligodendrocytes, and microglia were excluded from the counts. Neuronal counts were used to determine group means and variances, and comparisons among groups were analyzed using a one-way ANOVA and a NewmanKeuls post hoc test. The experiments were controlled at two levels. Neuronal counts in the contralateral ventral horn always served as controls for the ipsilateral ventral horn in lesioned null mice. In addition, neuron counts in wt mice served as strain controls.

Immunohistochemistry for signal transduction proteins. The expression and localization patterns of nNOS, iNOS, Fas, phospho ${ }^{\text {Ser15 }}$-p53, and caspase- 8 were examined in spinal MNs during apoptosis at the lightmicroscopic level in rats and mice. Animals received a unilateral SNA and were anesthetized and perfusion fixed at 2, 4, 5, 7, and $10 \mathrm{~d}$ after lesion ( $n=6$ animals per time point). The spinal cords were prepared as described above. Serially cut sections were systematically random sampled for immunohistochemical processing and subsequent counting of immunopositive neuronal cell bodies. After a random start, a one-in-five series of sections from the lumbosacral spinal cord was subsampled for immunohistochemical analyses. Proteins were detected using a standard immunoperoxidase method with diaminobenzidine (DAB) as chromogen. nNOS was detected with four different affinity-purified rabbit polyclonal antibodies obtained from Transduction Laboratories (Lexington, KY), Upstate Biotechnology (Lake Placid, NY), Chemicon (Temecula, CA), and ImmunoStar (Hudson, WI). iNOS was detected with two monoclonal antibodies purchased from Transduction Laboratories and Santa Cruz Biotechnology (Santa Cruz, CA) and four different polyclonal antibodies obtained from Transduction Laboratories, Upstate Biotechnology, Incstar (Stillwater, MN), and Sigma (St. Louis, MO). Fas was detected with a monoclonal antibody (BD Biosciences, Franklin Lake, NJ). Full-length and cleaved forms of caspase- 8 were detected with a polyclonal antibody (NeoMarker, Fremont, CA), and a monoclonal antibody specific for the small subunit of cleaved capsase-8 (Cell Signaling, Beverly, MA) was used. Phosphorylated p53 was detected with a rabbit antibody to serine- 15 phosphorylated p53 (Cell Signaling). The specificities of these antibodies were evaluated by immunoblotting or have been evaluated previously (Northington et al., 1996; Martin et al., 2001; Martin and Liu, 2002a; Graham et al., 2004). Negative control sections were incubated in comparable dilutions of IgG or with the primary or secondary antibody omitted. For iNOS and nNOS immunostaining, spinal cord sections from iNOS ${ }^{-1-}$ and $\mathrm{nNOS}^{-1-}$ mice were used also as negative controls. Immunopositive neurons were counted as described previously (Martin and Liu, 2002a).

Immunohistochemistry for DNA damage, oxidative stress, and DNA repair enzymes. Mice with NOS gene deletions and rats received a unilateral SNA and were killed by an overdose of sodium pentobarbital and perfusion fixation (4\% paraformaldehyde) at 2, 4, 5, 7, and $10 \mathrm{~d}$ after lesion ( $n=6$ animals per time point). Six-week-old tg SOD1 mice received a unilateral SNA and were perfusion fixed at 2, 4 , and $5 \mathrm{~d}$ after lesion. The spinal cords were removed from the vertebral column and cryoprotected in phosphate-buffered $20 \%$ glycerol. An additional group of wt and mSOD1 mice with SNA ( $n=4$ mice per genotype) were perfused, and samples of the spinal cord were embedded in plastic. A peroxidase-antiperoxidase detection method was used for immunocytochemical staining of free-floating lumbar spinal cord sections with DAB as chromogen. Two different forms of nucleic acid damage were assessed. Hydroxyl radical damage to DNA and RNA was detected with monoclonal antibodies to 8-hydroxy-2-deoxyguanosine (OHdG), obtained from QED Bioscience (San Diego, CA) and OXIS International (Portland, OR). These antibodies to OHdG have been evaluated for specificity by multiple approaches (Al-Abdulla and Martin, 1998; Martin et al., 1999). In competition experiments, sections were reacted with an antibody to $\mathrm{OHdG}$ that was incubated at $4^{\circ} \mathrm{C}$ for $24 \mathrm{~h}$ with 1000 -fold concentrations of OHdG, 8-hydroxyguanosine, or guanosine (Martin et al., 1999). As additional controls for staining specificity, it has been shown that OHdG immunoreactivity (IR) is attenuated by digestion with DNase $(5-10 \mathrm{mg} /$ $\mathrm{ml}$ ) or RNase (11-50 mg/ml) before incubation with OHdG antibody (Martin et al., 1999). A monoclonal antibody (Alexis Biochemicals, San Diego, CA) to single-stranded DNA (ssDNA) was used. The ssDNA immunodetection protocol requires pretreatment of sections with 0.2 $\mathrm{mg} / \mathrm{ml}$ saponin and $20 \mu \mathrm{g} / \mathrm{ml}$ proteinase $\mathrm{K}$ ( $20 \mathrm{~min}$ at room temperature) and then with $50 \%$ formamide $\left(20 \mathrm{~min}\right.$ at $\left.56^{\circ} \mathrm{C}\right)$ for DNA denaturation. Staining for ssDNA has been reported to be a specific and sensitive method for the detection of apoptotic cells (Frankfurt et al., 1996). Tyrosine nitration was used as a footprint indicator of $\mathrm{ONOO}^{-}$formation (Reiter et al., 2000). Spinal cord sections were incubated with a mouse monoclonal antibody to nitrotyrosine (Upstate Biotechnology). To determine whether NOS gene deletions altered the level of basal constitutive DNA repair proteins, we evaluated 8-oxoguanine (8-oxoG) DNAglycosylase (Ogg1), which catalyzes the release of 8 -hydroxyguanine 
opposite the pyrimidine from DNA (Boiteux and Radicella, 2000), and apurinic/apyrimidinic endonuclease (APE), which is a multifunctional enzyme responsible for repairing abasic sites in DNA (Christmann et al., 2003). Ogg1 was detected with a polyclonal antibody (Novus Biologicals, Littleton, CO). APE was detected with a monoclonal antibody (Affinity Bioreagents, Golden, CO).

Neurons showing immunopositivity in the ipsilateral and contralateral spinal ventral horns were counted at $1000 \times$ magnification in subsampled sections from each mouse or rat by an observer unaware of experimental history. For OHdG and ssDNA, only MNs with nuclear staining were counted. For nitrotyrosine staining, MNs with nuclear and cytoplasmic IR were counted. Careful focusing through the $z$-axis was used to distinguish nuclear labeling from cytoplasmic labeling. Group means and variances were evaluated statistically by one-way ANOVA and a Newman-Keuls post hoc test.

NADPH diaphorase histochemistry. NADPH diaphorase histochemistry is a method to specifically detect cells that can produce NO (Hope et al., 1991). All animals were perfusion fixed identically with $4 \%$ paraformaldehyde for this assay. Free-floating rat and mouse spinal cord sections were rinsed in $0.1 \mathrm{M}$ phosphate buffer $(\mathrm{PB})$ and incubated in an enzyme reaction solution containing $0.1 \mathrm{M} \mathrm{PB}, \mathrm{pH} 7.8,1 \mathrm{~mm}$ NADPH, 0.8 mM nitroblue tetrazolium, 8 mu monosodium malate, $10 \%$ DMSO, and $0.8 \%$ Triton X-100. The sections were reacted at room temperature for 30 $\mathrm{min}$, transferred to $\mathrm{PB}$, rinsed for $30 \mathrm{~min}$, and mounted on glass slides. Negative controls were done by replacing the NADPH $\beta$-isomer with $\alpha$-isomer, using spinal cord sections from nNOS ${ }^{-1-}$ and $\mathrm{iNOS}^{-1-}$ mice, and preincubating sections in iNOS inhibitor $S$-methylisothiourea sulfate (Santa Cruz Biotechnology).

$\mathrm{NO}$ and $\mathrm{ONOO}^{-}$imaging. $\mathrm{NO}$ and $\mathrm{ONOO}^{-}$productions in MNs in vivo were tracked using 1,2-diaminoanthraquinone (DAA; Molecular Probes, Eugene, OR) and 6-carboxy-2', $7^{\prime}$-dichlorohydrofluorescein diacetate di(acetoxymethyl ester) ( $\mathrm{H}_{2} \mathrm{DCFDA}$; Molecular Probes), respectively. As an aromatic vicinal diamine, DAA is nonfluorescent, but it reacts selectively with $\mathrm{NO}$ to yield a fluorescent product (Heiduschka and Thanos, 1998; Chen et al., 2001; von Bohlen und Halbach et al., 2002). $\mathrm{H}_{2}$ DCFDA has been used to track $\mathrm{ONOO}^{-}$in embryonic MNs in vitro (Estévez et al., 1999), although it is not specific for only $\mathrm{ONOO}^{-}$because it can detect other oxidants. Tracers were prepared in Influx (Molecular Probes) pinocytic cell-loading reagent. MNs were loaded in vivo by bilateral injection of DAA or $\mathrm{H}_{2}$ DCFDA into the gastrocnemius. The tracers are endocytosed at the neuromuscular junction and transported retrogradely. One day later, the animals received a unilateral SNA. The contralateral nonlesioned side served as a control. As a negative control, $\mathrm{N}^{\mathrm{G}}$-nitro-L-arginine methyl ester (L-NAME) was injected $(50 \mathrm{mg} / \mathrm{kg}$, i.p.) to inhibit all forms of NOS.

Single-cell densitometry. The NADPH diaphorase, $\mathrm{NO}$, and $\mathrm{ONOO}^{-}$ histochemical preparations of the spinal cord were analyzed quantitatively with single-cell densitometry (Shaikh and Martin, 2002). Images of nonlesioned and lesioned lumbar MNs were captured photographically on black-and-white film at $1000 \times$ magnification by an observer unaware of the case history. For each case, $\sim 50$ neurons, cut through the approximate cell center as judged by the nucleus, were acquired from lesioned and nonlesioned sides from each animal. The films of individual MNs were scanned and saved as TiFF files. For each neuron, measurements were obtained by delineating the cell of interest using densitometry software (Inquiry; Loats Associates, Westminster, MD). Relative enzyme activity and DAA or $\mathrm{H}_{2}$ DCFDA fluorescence intensity were reflected by the average-integrated intensity of film emulsion grain density. Group means and variances were evaluated statistically by one-way ANOVA and a Newman-Keuls post hoc test.

Immunoblotting. Fas, iNOS, nNOS, and cleaved caspase- 8 protein levels were detected by immunoblotting during the progression of $\mathrm{MN}$ apoptosis. Ogg1 levels were examined in nonlesioned NOS null mice. The antibodies used were the same as those used for immunohistochemistry. Samples of lumbar spinal cord ventral horn columns (ipsilateral and contralateral) were collected at 2-5 d after SNA for tissue homogenization and immunoblotting. Animals were deeply anesthetized with sodium pentobarbital and decapitated, and the spinal cord was removed quickly and placed in ice-cold dissection medium. Under a microsurgical stereomicroscope, the lumbar spinal cord was dissected segment by segment. Spinal cord segments L3-L6 and S1-S3 were isolated as transverse slabs. Using iridectomy scissors and a number 11 scalpel blade, the ventral horn gray matter on the ipsilateral (lesioned) and contralateral (control) sides was microdissected from the dorsal horn and the surrounding white matter funiculi and frozen quickly on dry ice. Spinal cord samples from ipsilateral and control sides were pooled from six rats for each time point. Microdissected spinal cord ventral horn samples were homogenized with a Brinkmann (Raleigh, NC) Polytron in ice-cold $20 \mathrm{~mm}$ Tris $\mathrm{HCl}$, pH 7.4, containing 10\% (wt/vol) sucrose, $200 \mathrm{~mm}$ mannitol, complete protease inhibitor cocktail (Roche, Welwyn Garden City, UK), 0.1 mM phenylmethylsulfonyl fluoride, $10 \mathrm{~mm}$ benzamidine, $1 \mathrm{~mm}$ EDTA, and 5 mM EGTA. Crude homogenates were sonicated for $15 \mathrm{~s}$ and supplemented with $20 \%$ (wt/vol) glycerol. Protein concentrations were measured by a Bio-Rad (Hercules, CA) protein assay with bovine serum albumin as a standard. Proteins from ipsilateral and contralateral spinal cord samples were subjected to $15 \%$ SDS-PAGE and transferred to nitrocellulose membrane by electroelution as described previously (Martin, 1999). The reliability of sample loading and electroblotting in each experiment was evaluated by staining nitrocellulose membranes with Ponceau $\mathrm{S}$ before immunoblotting. If transfer was not uniform, the blots were discarded and gels were run again. The blots were blocked with $2.5 \%$ nonfat dry milk with $0.1 \%$ Tween 20 in 50 mu Tris-buffered saline, $\mathrm{pH} 7.4$, and incubated overnight at $4^{\circ} \mathrm{C}$ with an antibody. The antibodies were used at concentrations for visualizing protein IR within the linear range (Lok and Martin, 2002). After the primary antibody incubation, the blots were washed and incubated with a horseradish peroxidaseconjugated secondary antibody $(0.2 \mu \mathrm{g} / \mathrm{ml})$, developed with enhanced chemiluminescence (Pierce, Rockford, IL), and exposed to x-ray film. The blots were then reprobed with a monoclonal antibody to synaptophysin (Boehringer Mannheim, Indianapolis, IN) or glyceraldehyde-3phosphate dehydrogenase (GAPDH) (Research Diagnostics, Flanders, $\mathrm{NJ}$ ) as a control for protein loading.

DNA repair activity. Ogg1 enzyme activity was determined in $\mathrm{nNOS}^{-/-}$, $\mathrm{iNOS}^{-1-}$, and wt mice using an in vitro DNA repair assay (Hollenbach et al., 1999). Cellular fractions from the forebrain and spinal cord were incubated with a 24-mer, duplex oligonucleotide containing 8 -oxoG at the 10th position ( $\mathrm{R} \& \mathrm{D}$ Systems, Minneapolis, $\mathrm{MN}$ ) that was end-labeled with digoxigenin-11-dideoxyuridine-5-triphosphase using terminal deoxynucleotidyl transferase. This synthetic oligonucleotide is suitable as a substrate for Ogg1 when hybridized to its complementary oligonucleotide (Hollenbach et al., 1999). Ogg1 catalyzes the removal of the 8-oxoG through cleavage of the DNA phosphodiester bond following Schiff base chemistry (Boiteux and Radicella, 2000). An identical oligonucleotide without the 8 -oxoG adduct was used as a negative control. Activity assays were done in a $20 \mu \mathrm{l}$ reaction volume containing buffer (20 mm Tris, pH 8.0, 1 mm EDTA, $1 \mathrm{~mm}$ DTT, and $0.1 \mathrm{mg} / \mathrm{ml} \mathrm{BSA}$ ), 1 pmol of oligonucleotide, and $40 \mu \mathrm{g}$ of nuclear fraction protein and incubated for $1 \mathrm{~h}$ at $37^{\circ} \mathrm{C}$. The reaction was terminated by the addition of alkaline gel loading buffer and heated to $95^{\circ} \mathrm{C}$ for $10 \mathrm{~min}$. The products were separated by $20 \%$ denaturing PAGE in the presence of $8 \mathrm{M}$ urea in Tris-borate EDTA. The gels were transferred to nylon membrane and probed with antibody to digoxigenin (Roche) as described previously (Martin et al., 2001) to visualized intact and cleaved oligonucleotide.

Antioxidant gene therapy and pharmacotherapy. We studied whether oxidative stress participates in the mechanisms of avulsion-induced MN apoptosis in the adult spinal cord by determining whether antioxidant therapies are neuroprotective. Transgenic and pharmacological therapies were used. A unilateral SNA was done on tg mice expressing normal human SOD1 $(n=6)$ and human G93A mSOD1 $(n=12)$ and on wt non-tg B6SJLF1/J mice $(n=6)$. For pharmacotherapies, Trolox (6hydroxy-2,5,7,8-tetramethylchroman-2-carboxylic acid) and ascorbic acid (vitamin C) were used as antioxidants. Trolox, a water and lipidsoluble vitamin $\mathrm{E}$ derivative is a cell-permeable free radical scavenger that can prevent radiation-induced and $\mathrm{ONOO}^{-}$-induced apoptosis in vitro (Salgo and Pryor, 1996) and methylmercury-induced neuronal apoptosis in vivo (Usuki et al., 2001). Trolox (Calbiochem, La Jolla, CA and Aldrich, Milwaukee, WI) was dissolved in ethanol/saline at a stock concentration of $50 \mathrm{mg} / \mathrm{ml}$. Studies showing the antioxidant actions of ascorbate 
are numerous (Carr and Frei, 1999). Ascorbate was dissolved in saline. Rats $(n=40)$ were treated daily starting $3 \mathrm{~d}$ before lesion through day 21 after lesion with Trolox (50 mg/kg, i.p.), ascorbic acid (50 mg/kg, i.p.), or the corresponding vehicle. Each treatment group included 10 animals. Mice and rats with test therapies were killed by perfusion fixation (4\% paraformaldehyde) at $21 \mathrm{~d}$ after lesion. In follow-up experiments with mSOD1 mice, additional postlesion time points were 2, 4, 5, 7, and $14 \mathrm{~d}$. After perfusion fixation, spinal cords were allowed to remain in situ for $2 \mathrm{~h}$ before they were removed from the vertebral column. The spinal cords were cryoprotected in 20\% glycerol-PBS, uniformly blocked, and frozen under pulverized dry ice. Transverse serial symmetrical sections $(40 \mu \mathrm{m})$ through the lumbosacral cords were cut using a sliding microtome. Serial sections from each mouse and rat spinal cord were mounted on glass slides and stained with cresyl violet for neuronal counting. $\mathrm{MN}$ counts in the ipsilateral and contralateral sides were determined by an operator unaware of sample experimental history at $1000 \times$ magnification using the stereological optical disector method (Calhoun et al., 1996; Martin et al., 1999). Neuronal counts were used to determine group means and variances, and comparisons among groups were performed using a one-way ANOVA and a post hoc Newman-Keuls test.

\section{Results}

\section{Adult MNs lacking functional Fas death receptors are} resistant to apoptosis

Lack of a functional Fas receptor conferred MN protection after SNA. At $21 \mathrm{~d}$ after SNA, wt C57BL/6J mice had a 56\% loss of ipsilateral lumbar MNs; in contrast, mice expressing nonfunctional Fas showed a $17 \%$ loss of ipsilateral lumbar MNs (Fig. $1 A, B)$. This effect was specific for Fas death receptor compared with another death receptor, because deletion of the low-affinity nerve growth factor (NGF) receptor p75 did not influence the amount of MN loss after SNA (Fig. 1A). Deletion of Fas ligand protected partially against the $\mathrm{MN}$ apoptosis (Fig. $1 A, C$ ). Immunohistochemistry revealed an upregulation in Fas protein in lesioned rat MNs by $5 \mathrm{~d}$ after SNA (Fig. $1 D, E$ ). Immunoblotting of discretely microdissected ventral horn samples showed an increase in Fas protein in the ipsilateral lumbar spinal cord at 5-10 $\mathrm{d}$ after SNA (Fig. 1I). Increased levels of Fas death receptor protein in the ipsilateral ventral horn at $5 \mathrm{~d}$ after SNA were accompanied by increased levels of the active cleavage product of caspase- 8 (the p10 subunit) and other processed caspase- 8 products (the $\mathrm{p} 43 / 41$ subunit) as shown by immunoblotting (Fig. $1 H$ ) and immunohistochemistry (Fig. $1 I$ ).

The Fas gene promoter has a p53-response element (Müller et al., 1998), and p53 gene deletion protects strongly against MN apoptosis induced by SNA (Martin and Liu, 2002a). Therefore, potential links between Fas and p53 were examined in apoptotic MNs. Upregulation of Fas in MNs after SNA was attenuated in p53 $3^{-1-}$ mice (Fig. $1 F$ ), indicating that Fas is downstream to p53. In contrast, p53 activation, as indicated by the detection of phosphoSer ${ }^{15}$-p53, was present in lesioned MNs in mice with mutant Fas (Fig. 1G).

\section{Adult MNs deficient in nNOS and iNOS escape injury-induced apoptosis}

Normal adult MNs expressed constitutively nNOS and iNOS but not eNOS (Fig. 2). The presence of nNOS IR in MNs (Fig. $2 F$ ) was confirmed with four different antibodies, and, similarly, the presence of iNOS IR in MNs (Fig. 2G) was confirmed with six different antibodies. Lumbar MNs in nNOS ${ }^{-1-}$ mice did not show IR for nNOS, and MNs in iNOS ${ }^{-1-}$ did not show IR for iNOS, but nNOS $^{-1-}$ mice had iNOS-positive MNs and iNOS ${ }^{-1-}$ mice had nNOS-positive MNs (data not shown).

Mice deficient in nNOS and iNOS were protected from the apoptosis of MNs induced by SNA. At $21 \mathrm{~d}$ after SNA,
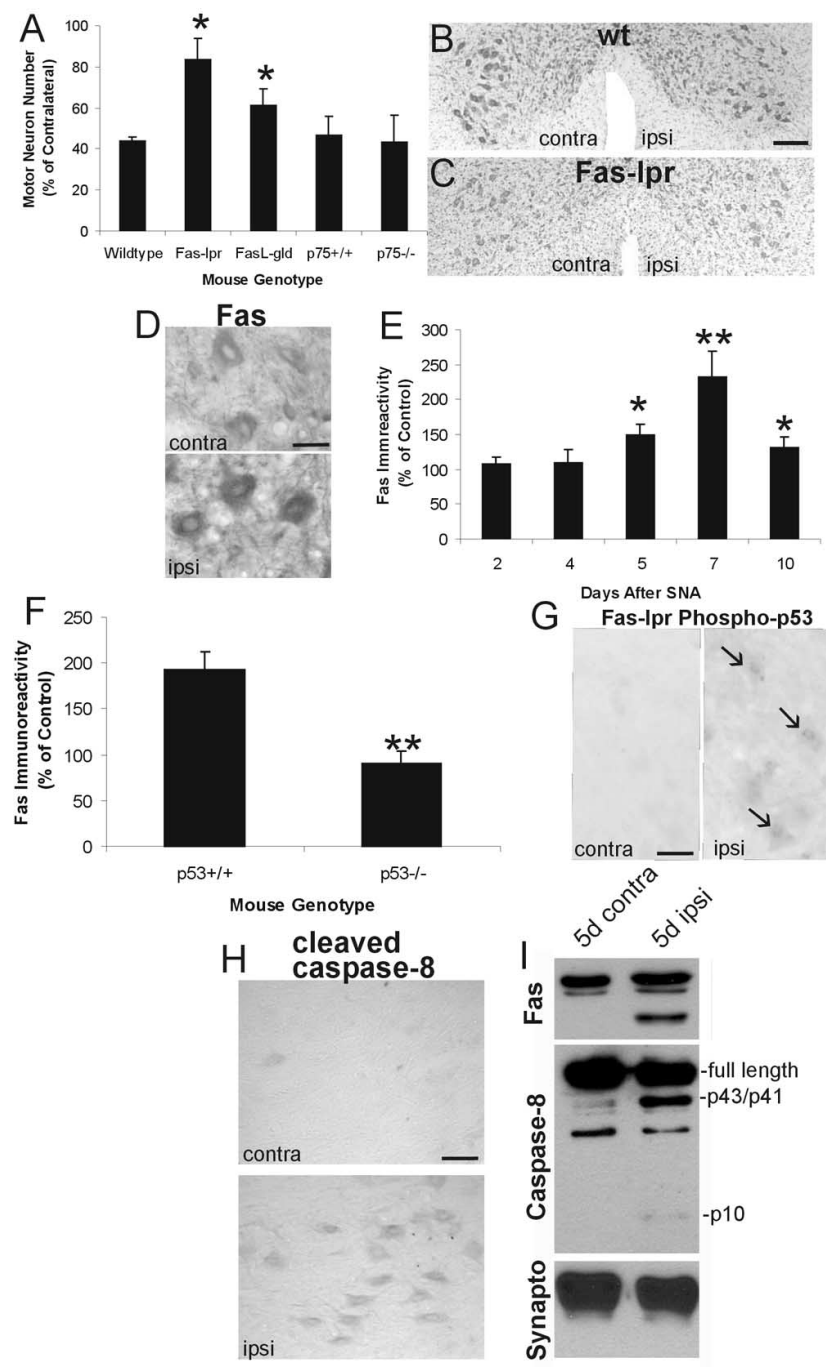

Figure 1. Fas mediates apoptosis of adult spinal MNs. $\boldsymbol{A}$, Bar graph showing MN survival in mice with different genotypes at $21 \mathrm{~d}$ after unilateral SNA. Spontaneously mutant mice, Fas ${ }^{\text {Ipr }}$ and FasL ${ }^{\text {gld }}$, were protected against the MN apoptosis, but MNs in mice deficient in p75 were not protected. The values are mean \pm SD. The asterisk denotes a significant difference ( $p<$ 0.05 ) from wt control ( $n=6-10$ mice per genotype). $\boldsymbol{B}$, Transverse section of the lumbar spinal cord of a wt mouse showing the loss of MNs in the side of spinal cord ipsilateral to the SNA at $21 \mathrm{~d}$ (cresyl violet staining). The contralateral side is the nonlesioned control side. C, Transverse section of the lumbar spinal cord in a Fas ${ }^{\mathrm{Ipr}}$ mouse showing MN preservation in the side of the spinal cord ipsilateral to the SNA at $21 \mathrm{~d}$ (cresyl violet staining). The contralateral side is the control side. D, Immunolocalization of Fas (dark staining) shows elevated IR in ipsilateral MNs compared with control contralateral MNs in the rat lumbar spinal cord at $5 \mathrm{~d}$ after SNA. $\boldsymbol{E}$, Quantitative analysis of Fas IR in MNs after SNA using single-cell densitometry. The values are mean \pm SD. ${ }^{*} p<0.05,{ }^{* *} p<0.01$, significant difference from contralateral control MNs ( $n=$ 6 rats per time point). $\boldsymbol{F}$, Bar graph of Fas IR measurements in MNs of $\mathrm{p} 53^{+/+}$and $\mathrm{p} 53^{-1-}$ mice at $7 \mathrm{~d}$ after SNA ( $n=6$ mice per genotype). The values are mean \pm SD. $p 53$ gene deletion significantly attenuated $(p<0.01)$ the Fas upregulation in MNs. $\mathbf{G}$, Immunolocalization of phosphor-Ser ${ }^{15}$-p53 in Fas-Ipr mice with SNA. The Fas-Ipr mutation did not prevent the activation of $\mathrm{p} 53$ in ipsilateral lesioned MNs (arrows), because phosphor-Ser ${ }^{15}-\mathrm{p} 53$ is enriched in the nuclei of MNs. No labeling is present in contralateral MNs. $\boldsymbol{H}$, Immunolocalization of cleaved caspase-8 (using an antibody specifically for the active form of caspase-8) in ipsilateral MNs compared with contralateral MNs at $7 \mathrm{~d}$ after SNA in the rat. Numerous MNs have cleaved caspase-8 IR on the ipsilateral side compared with very rarely immunopositive MNs on the contralateral side. I, Western blots for Fas, caspase-8, and synaptophysin (Synapto) in lumbar spinal cord ventral horn microdissections of the rat ( $n=4$ pooled rat samples per lane) at $5 \mathrm{~d}$ after SNA. Ipsilateral samples show increased Fas and formation of the active cleaved subunit of caspase- 8 (the p10 subunit). Synaptophysin served as a protein loading control. The identity of the lower-molecular weight-immunoreactive band in the Fas blot ( $5 \mathrm{~d}$ ipsi) is unknown but has been seen before in other neurons undergoing Fas-regulated apoptosis (Graham et al., 2004). Scale bars: $\boldsymbol{B}, \boldsymbol{C}, 450 \mu \mathrm{m} ; \boldsymbol{D}, 54 \mu \mathrm{m} ; \boldsymbol{G}, 77 \mu \mathrm{m} ; \boldsymbol{H}, 77 \mu \mathrm{m}$. ipsi, Ipsilateral; contra, contralateral. 


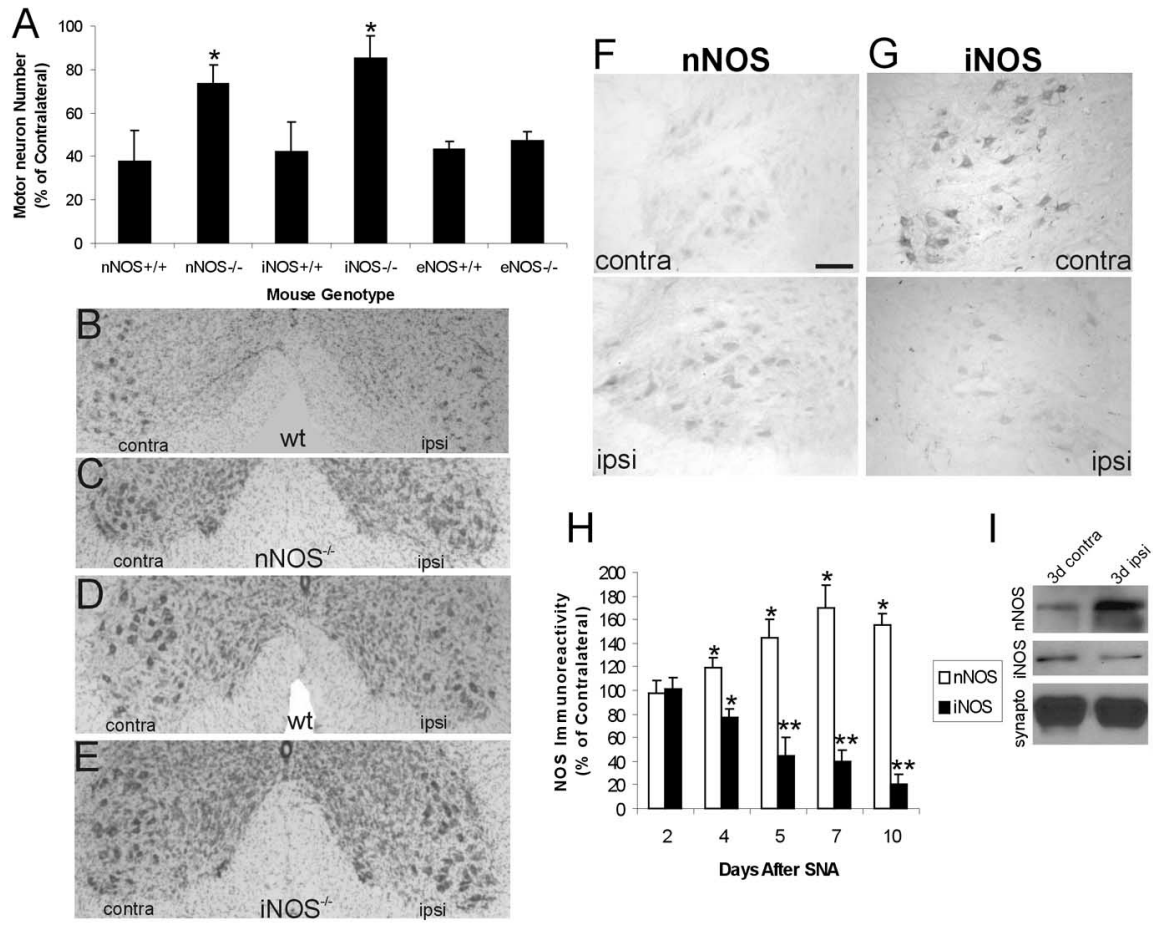

Figure 2. NOS mediates apoptosis of adult spinal MNs. $\boldsymbol{A}$, Bar graph showing MN survival in mice with different NOS genotypes at $21 \mathrm{~d}$ after unilateral SNA. Knock-out of nNOS and iNOS protected MNs against apoptosis, but mice deficient in eNOS were not protected. The values are mean \pm SD. The asterisk denotes a significant difference $(p<0.05)$ from wt control $(n=6-10$ mice per genotype). $\boldsymbol{B}$, Transverse section of the lumbar spinal cord of a genetic background wt mouse with nNOS showing the loss of MNs in the side ipsilateral to the SNA at $21 \mathrm{~d}$ (cresyl violet staining). The contralateral side is the control side. C, Transverse section of the lumbar spinal cord in an nNOS ${ }^{-1-}$ mouse showing preservation of ipsilateral MNs at $21 \mathrm{~d}$ after SNA (cresyl violet staining). The contralateral side is the control side. $D$, Transverse section of the lumbar spinal cord of a genetic background wt mouse with iNOS showing the loss of ipsilateral MNs at $21 \mathrm{~d}$ after SNA (cresyl violet staining). The contralateral side is the control side. $\boldsymbol{E}$, Transverse section of the lumbar spinal cord in an iNOS ${ }^{-1-}$ mouse showing MN preservation in the side of spinal cord ipsilateral to the SNA at $21 \mathrm{~d}$ (cresyl violet staining). The contralateral side is the control side. $\boldsymbol{F}$, Immunolocalization of nNOS shows elevated nNOS IR in ipsilateral MNs compared with control contralateral MNs in the rat lumbar spinal cord at $7 \mathrm{~d}$ after SNA. G, Immunolocalization of iNOS (dark staining) shows reduced iNOS IR in ipsilateral MNs compared with control contralateral MNs in the rat lumbar spinal cord at $5 \mathrm{~d}$ after SNA. $\boldsymbol{H}$, Quantitative analysis of nNOS and iNOS IR in MNs after SNA using single-cell densitometry. The values are mean \pm SD. ${ }^{*} p<0.05,{ }^{* *} p<0.01$, significant difference from contralateral control MNs ( $n=6$ rats per time point). I, Western blots for nNOS, iNOS, and synaptophysin (synapto) in lumbar spinal cord ventral horn microdissections of the rat ( $n=4$ pooled rat samples per lane) at $3 \mathrm{~d}$ after SNA. Ipsilateral samples show increased nNOS and decreased iNOS. Synaptophysin served as a protein loading control. Scale bars: $\boldsymbol{B}-\boldsymbol{E}, 360 \mu \mathrm{m} ; \boldsymbol{F}, \mathbf{G}, 405 \mu \mathrm{m}$. ipsi, Ipsilateral; contra, contralateral.

butions of iNOS and nNOS to the NADPH diaphorase staining in MNs. The NOS isoforms contributed differentially to the constitutive NADPH diaphorase activity in MNs (Fig. $3 C$ ). MNs in iNOS $^{-1-}$ mice had very low basal NADPH diaphorase activity, but enzyme activity was enriched in smaller neurons and neuropil in the dorsal horn (substantia gelatinosa) and around the central canal; in contrast, $\mathrm{MNs}$ in $\mathrm{nNOS}^{-1-}$ mice retained wt-like levels of $\mathrm{NADPH}$ diaphorase activity, but smaller interneuron-like neurons throughout the spinal cord and the neuropil of the substantia gelatinosa did not possess activity (Fig. 3C). Incubation of sections from wt and nNOS ${ }^{-1-}$ mice with $100 \mu \mathrm{M}$ iNOS inhibitor attenuated the NADPH diaphorase staining in MNs (data not shown). Because the basal level of iNOS and the induced level of nNOS could contribute to the $\mathrm{MN}$ apoptosis, we measured NADPH diaphorase activity in $\mathrm{nNOS}^{-1-}$ and iNOS $^{-1-}$ mice after SNA. The SNAinduced NADPH diaphorase activity in MNs was significantly attenuated in both $\mathrm{nNOS}^{-1-}$ and iNOS $^{-1-}$ mice, but the block in the induction of NADPH diaphorase staining was vastly greater in iNOS $^{-1-}$ mice compared with $\mathrm{nNOS}^{-/-}$ mice (Fig. $3 D, E$ ).

NO synthesis in MNs was assessed using the DAA assay (Fig. $3 F, G$ ). An NO signal was barely detectable in nonlesioned MNs. NO production was elevated significantly in lesioned MNs. NO levels progressively increased in ipsilateral MNs during the first postlesion week, peaking at 5 d after lesion (Fig. 3E). L-NAME blocked the DAA fluorescence (data not shown).

\section{Injured MNs generate \\ $\mathrm{ONOO}^{-}$preapoptotically}

B6129SF2/J mice (controls for nNOS ${ }^{-1-}$ mice) and B6129PF2/J mice (controls for iNOS $^{-1-}$ mice) had a 62 and $57 \%$ elimination of lumbar MNs, respectively (Fig. $2 A-E$ ). In contrast, $\mathrm{MN}$ loss in nNOS $^{-1-}$ and iNOS $^{-1-}$ mice was 26 and $15 \%$, respectively. There was no statistically significant difference between the amount of neuroprotection in iNOS and nNOS mice (Fig. 2A). Mice deficient in eNOS were not protected against the loss of MNs (Fig. 2A). Immunohistochemistry and immunoblotting revealed an increase in nNOS protein levels in MNs in the ipsilateral lumbar spinal cord compared with contralateral IR (Fig. 2 F, $H, I$ ). In contrast, iNOS levels in injured MNs decreased compared with control MNs (Fig. 2G-I).

The presence of NOS was assessed also by NADPH diaphorase staining. NADPH diaphorase staining was observed in nonlesioned MNs, and enzyme activity increased in injured MNs (Fig. $3 A, B)$, consistent with other studies ( Wu, 1993). Enzyme activity was quantified in individual MNs using single-cell densitometry (Skaikh and Martin, 2002). NADPH diaphorase activity progressively increased in ipsilateral MNs during the first postlesion week (Fig. $3 B$ ). NOS $^{-1-}$ mice were used to determine the contri-
$\mathrm{ONOO}^{-}$generation in MNs was assessed using the $\mathrm{H}_{2}$ DCFDA assay (Fig. $3 \mathrm{H}, I$ ). The $\mathrm{ONOO}^{-}$signal was not detectable in nonlesioned $\mathrm{MNs}$ (Fig. $3 \mathrm{H}$ ). $\mathrm{ONOO}^{-}$production was elevated in lesioned MNs at $5 \mathrm{~d}$ after lesion (Fig. 3I). Immunostaining for nitrotyrosine was used as a footprint for the presence of $\mathrm{ONOO}^{-}$ in MNs. A low level of nitrotyrosine staining was present in subsets of nonlesioned MNs (Fig. 4). In lesioned MNs, nitrotyrosine staining was increased (Fig. $4 A$, bottom). The number of MNs immunoreactive for nitrotyrosine was increased by $4 \mathrm{~d}$ after SNA, peaking at $5 \mathrm{~d}$ after lesion, and declining thereafter. Nitrotyrosine IR was present in the cell bodies, axons, and nucleus of lesioned MNs. Staining with nitrotyrosine antibodies was blocked by preadsorption of antibody with 3-nitrotyrosine but was unaffected by tyrosine (data not shown).

DNA and RNA damage accumulates rapidly in injured MNs before apoptosis

Adult MN apoptosis induced by SNA is p53 dependent (Martin and Liu, 2002a). Activated p53 is found in MNs preapoptotically (Fig. 1G) (Martin and Liu, 2002a), indicative of DNA damage 
(Jayaraman and Prives, 1995). Therefore, MNs were evaluated for DNA damage at early, preapoptotic, postlesion time points (Fig. 5). DNA damage was assessed with two different immunomarkers. OHdG IR was seen in the nucleus and cytoplasm of MNs (Fig. 5A). This IR is specific because the intensity of cytoplasmic and nuclear immunolabeling can be altered, respectively, by RNase and DNase pretreatment and by preadsorption of antibody with 8-hydroxyguanosine and $\mathrm{OHdG}$, indicating hydroxyl adduct modified RNA and DNA (Al-Abdulla and Martin, 1998; Martin et al., 1999). Both the overall intensity of staining in labeled MNs and the number OHdG-immunopositive MNs changed in the spinal cord after SNA (Fig. 5A). The number of MNs with nuclear OHdG IR was increased ipsilaterally during and after the first postlesion week (Fig. 5A). The increase was progressive between 2 and $5 \mathrm{~d}$, peaking at $5 \mathrm{~d}$, and then the number of immunopositive MNs declined. Immunostaining for ssDNA was localized as particles within the cytoplasm, possibly corresponding to mitochondrial DNA labeling, and as nuclear staining (Fig. 5B). The nuclear staining of ssDNA became very prominent after SNA (Fig. 5B). The number of MNs with ssDNA was also increased in the ipsilateral lumbar cord (Fig. 5B). ssDNA ${ }^{+}$MNs were higher than control at 4-10 d after lesion. A maximal level was found at $10 \mathrm{~d}$ after lesion. To determine the contribution of NOS to the mechanisms of DNA damage accumulation in MNs after injury, OHdG and ssDNA staining was assessed in $\mathrm{nNOS}^{-/-}$and iNOS $^{-1-}$ mice with SNA. The absence of nNOS and iNOS both attenuated the accumulation of DNA damage in injured MNs (Fig. 5C). This effect was much greater with $i N O S$ gene deletion (Fig. 5C). Absence of eNOS did not affect the accumulation of DNA damage in injured MNs (Fig. $5 C$ ). Because the expression of catalytically active NOS (diaphorase activity) seems to come primarily from iNOS, yet both $i N O S$ and $n N O S$ gene deletions protect MNs from apoptosis, an alternative mechanism for neuroprotection was explored in nNOS ${ }^{-1-}$ mice. $n N O S$ gene deletion was associated with an upregulation of basal Ogg1 protein in spinal cord MNs compared with wt mice as shown by immunohistochemistry (Fig. 5D) and Western blotting (Fig. 5E). Moreover, Ogg1 functional activity was elevated in $\mathrm{nNOS}^{-1-}$ mice compared with wt mice as shown by the ability to remove 8 -oxoG from oligonucleotide (Fig. $5 F$ ). The levels of Oggl in iNOS ${ }^{-1-}$ mice were not greater
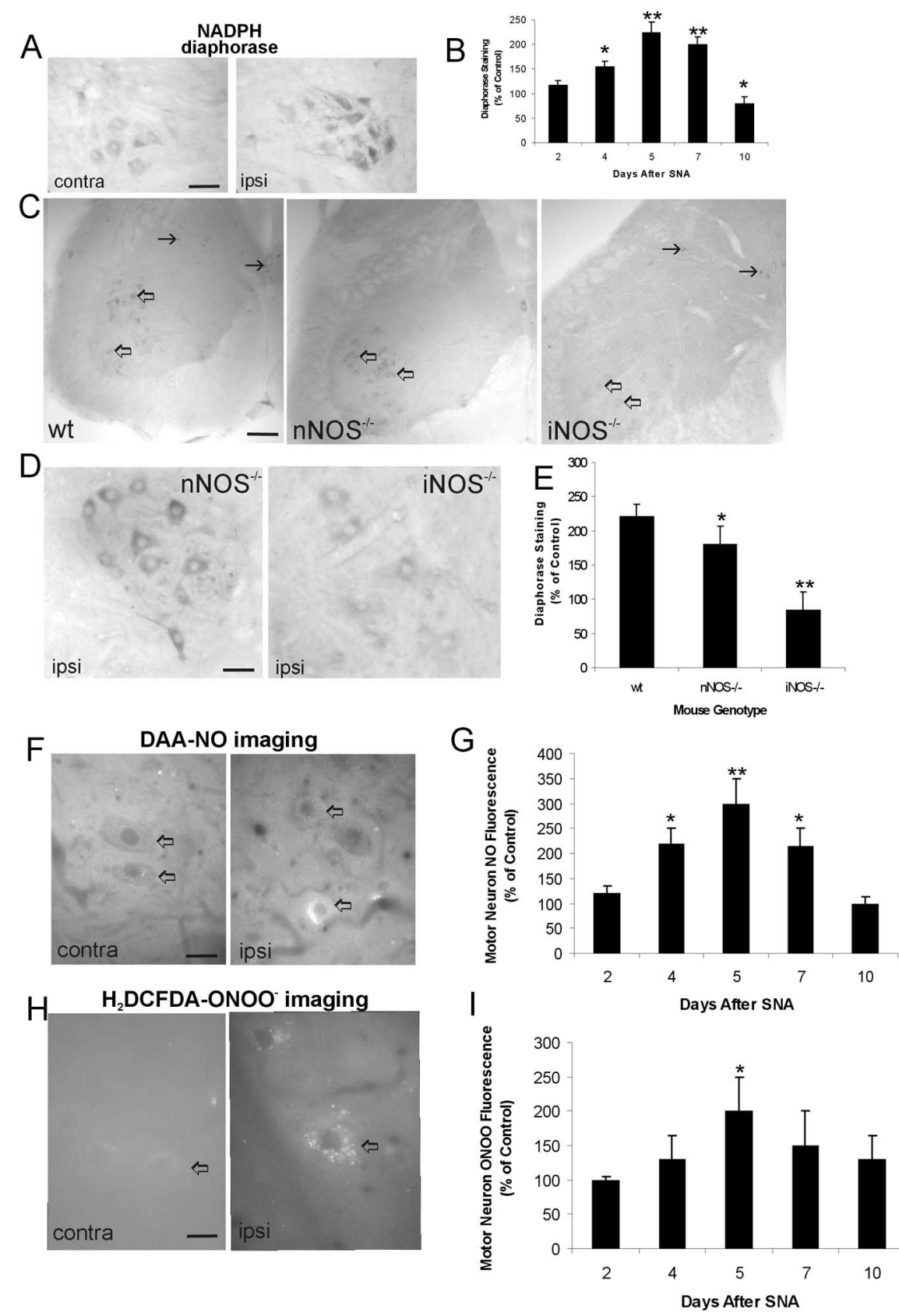

Figure 3. Increased NADPH diaphorase activity and elevated productions of $\mathrm{NO}$ and $0 \mathrm{NOO}^{-}$occur early and transiently during adult MN apoptosis. A, NADPH diaphorase enzyme histochemistry shows elevated activity in ipsilateral MNs compared with contralateral MNs at $5 \mathrm{~d}$ after SNA. $\boldsymbol{B}$, Quantitative analysis of NADPH diaphorase reaction product in MNs after SNA using single-cell densitometry. The values are mean $\pm S D .{ }^{*} p<0.05,{ }^{* *} p<0.01$, significant difference from contralateral control MNs ( $n=6$ rats per time point). C, NADPH diaphorase staining in the spinal cord of nonlesioned wt, $n N O S^{-1-}$, and $\mathrm{iNOS}^{-1-}$ mice. In wt mice, diaphorase activity is localized to MNs (open arrows) and small neurons (arrows) in the dorsal horn and around the central canal. In nNOS ${ }^{-1-}$ mice, MNs show diaphorase staining (open arrows), but staining of small neurons is absent. In iNOS $^{-1-}$ mice, small neurons (arrows) show staining, but MN (open arrows) staining is barely detectable or absent. $\boldsymbol{D}$, At $5 \mathrm{~d}$ after SNA, MNs in nNOS ${ }^{-1-}$ mice still have high diaphorase activity (see $\boldsymbol{E}$ for quantification), whereas the increase in diaphorase activity in $\mathrm{MNs}$ in iNOS ${ }^{-1-}$ mice is blocked completely. $E$, Quantitative analysis of NADPH diaphorase reaction product in $\mathrm{L} 5 \mathrm{MNs}$ of wt, nNOS ${ }^{-1-}$, and iNOS ${ }^{-1-}$ MNs after SNA using single-cell densitometry. The values are mean \pm SD. ${ }^{*} p<0.05,{ }^{* *} p<$ 0.01 , significant difference from contralateral control MNs ( $n=5$ mice per time point). $\boldsymbol{F}$, DAA fluorescence for N0 is increased in ipsilateral MNs (open arrows) after SNA compared with nonlesioned contralateral MNs. G, Quantitative analysis of DAA fluorescence in MNs after SNA using single-cell densitometry. The values are mean \pm SD. ${ }^{*} p<0.05,{ }^{* *} p<0.01$, significant difference from contralateral control MNs ( $n=6$ rats per time point). $\boldsymbol{H}, \mathrm{H}_{2} \mathrm{DCFDA}$ fluorescence for $0 \mathrm{NOO}^{-}$is increased in ipsilateral MNs (open arrow) compared with same-section contralateral MNs after SNA. I, Quantitative analysis of $\mathrm{H}_{2} \mathrm{DCFDA}$ fluorescence in MNs after SNA using single-cell densitometry. The values are mean $\pm S D .{ }^{*} p<0.05$, significant difference from contralateral control MNs ( $n=6$ rats per time point). Scale bars: $\boldsymbol{A}, 64 \mu \mathrm{m} ; \boldsymbol{C}, 270 \mu \mathrm{m} ; \boldsymbol{D}, 50 \mu \mathrm{m} ; \boldsymbol{F}, 41 \mu \mathrm{m} ; \boldsymbol{H}, 34 \mu \mathrm{m}$. ipsi, Ipsilateral; contra, contralateral. 

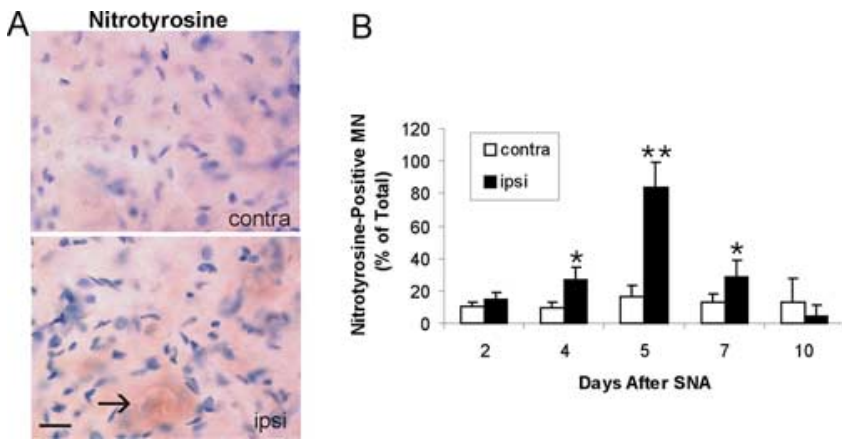

Figure 4. Protein nitration is increased in MNs after SNA.A, IR for nitrotyrosine is enriched in subsets of ipsilateral MNs (arrow) but not in contralateral MNs after SNA in the rat. Protein nitration is present in the cytoplasm and in the nucleus (arrow). The nuclear nitrotyrosine IR is associated with the perimeter of the nucleolus and fine strands and granules within the nuclear matrix (arrow). The immunoperoxidase sections are counterstained with cresyl violet. Scale bar, $27 \mu \mathrm{m}$. $\boldsymbol{B}$, Counts of nitrotyrosine-immunopositive MNs after SNA. The values are mean \pm SD. ${ }^{*} p<0.05,{ }^{* *} p<0.01$, significant difference from contralateral control MNs ( $n=6$ rats per time point). ipsi, Ipsilateral; contra, contralateral.

than wt mice, and APE appeared to be less affected (data not shown).

\section{Antioxidant therapy protects adult MNs from apoptosis}

Pharmacological and transgenic antioxidant therapies were used as interventions to study whether oxidative stress participates in the mechanisms adult $\mathrm{MN}$ apoptosis. Trolox treatment had a significant protective effect on MNs after SNA (Fig. 6A), but ascorbate treatment failed to provide a protective effect on $\mathrm{MN}$ survival (Fig. 6A). Tg mice overexpressing normal human SOD1 showed a significant attenuation in the $\mathrm{MN}$ apoptosis compared with wt non-tg mice (Fig. 6B).

\section{Mutant SOD1 worsens and accelerates injury-induced MN degeneration and converts the apoptotic phenotype to a necrotic phenotype}

The tg mice harboring human mSOD1 showed a significant worsening in the loss of MNs after SNA compared with wt non-tg mice (Fig. $6 B$ ). In mSOD1 mice with SNA, the rate of MN loss was faster compared with wt non-tg mice (Fig. 6C), and the accumulation of DNA damage in injured MNs was greater compared with wt non-tg mice (Fig. 6D). Moreover, the structural phenotype of the MN degeneration was changed in $\mathrm{MSOD} 1$ mice (Fig. 6E,F). In wt mice, MN degeneration induced by SNA always resembles apoptosis (Martin and Liu, 2002a) typified by cellular condensation with chromatin compaction into round masses (Fig. 6G,H). In mSOD1 mice with SNA, the structure of the $\mathrm{MN}$ degeneration was similar to necrosis, as indicated by the cellular swelling, cytoplasmic vacuolation, and the absence of nuclear pyknosis and chromatin condensation (Fig. 6E,F). mSOD1 mice were examined for SNA-induced changes in Fas and NOS. Presymptomatic mSOD1 mice had no immunocytochemically detectable Fas staining of MN cell bodies in the contralateral spinal cord, but lesioned MNs were Fas positive by $2 \mathrm{~d}$ after lesion (Fig. 6I). Furthermore, in contrast to wt mice, iNOS protein was upregulated in injured MNs in mSOD1 mice (Fig. $6 J)$, but no remarkable changes were seen with nNOS after SNA (Fig. $6 \mathrm{~K}$ ).

\section{Discussion}

We investigated whether Fas and NOS function in adult MN apoptosis. Studies have implicated Fas in developmental apopto- sis of embryonic MNs in vitro (Raoul et al., 1999), axotomyinduced apoptosis of neonatal MNs in vivo (Ugolini et al., 2003), and in degeneration of embryonic MNs in vitro induced by mSOD1 (Raoul et al., 2002). Previous work has implicated NO, generated by nNOS or iNOS, and $\mathrm{ONOO}^{-}$in embryonic MN apoptosis in vitro induced by trophic factor deprivation (Estévez et al., 1998) and zinc-deficient SOD1 (Estévez et al., 1999) as well as $\mathrm{MN}$ degeneration in vivo in mSOD1 mice (Almer et al., 1999) and in human ALS (Beckman et al., 1993; Sasaki et al., 2000; Catania et al., 2001), but in these latter two settings, the contributions of apoptosis and NOS to the MN degeneration are controversial (Facchinetti et al., 1999; Son et al., 2001; Barbeito et al., 2004; Bruijn et al., 2004). The roles of Fas and NOS have not been assessed in a system of definite apoptosis in adult MNs. In our SNA model, the neurodegeneration is unequivocally apoptotic, and the dependence of this cell death on Bax and its regulation by p53 support this conclusion (Martin and Liu, 2002a). The capacity of $\mathrm{ONOO}^{-}$to generate DNA damage in MNs (Liu and Martin, 2001; Martin and Liu, 2002b) and the formation of ssDNA within the $\mathrm{MN}$ genome coincident with p53 activation (Martin and Liu, 2002a) places $\mathrm{ONOO}^{-}$as a suspect killer of MNs.

Our experiments show that Fas regulates apoptosis of adult MNs in the SNA model. Fas protein was upregulated in MNs at a time coinciding with formation of cleaved caspase- 8 , indicative of Fas engagement. However, Fas activation can have survivalpromoting actions (Desbarats et al., 2003); but, MNs in mice with a spontaneous loss-of-function mutation at the Fas locus were protected against apoptosis, similar to findings using a different apoptosis model (Graham et al., 2004). Another in vivo axotomy study has shown that Fas activation triggers $\mathrm{MN}$ death in the neonatal brainstem (Ugolini et al., 2003). Our findings with adult MNs are important because assumption that cell death mechanisms in adult and developing neurons are always similar can be inappropriate (Lesuisse and Martin, 2002), but, in this case, mechanisms regulating death of adult and developing MNs induced by injury have commonalities.

Fas is a member of a family of transmembrane cell surface receptors that include tumor necrosis factor receptors (TNFRs) and low-affinity $\mathrm{p} 75$ NGF receptor. Fas, but not p75, has a role in adult MN apoptosis. Another study showed that TNFR1 and TNFR2 appear to cooperate to induce MN degeneration in the adult brainstem, but individually these receptors did not mediate MN death (Raivich et al., 2002). Thus, there is differential selective involvement of cell surface death receptors in the mechanisms of MN death in vivo. FasL seems to be partly responsible for the activation of Fas because mice with a spontaneous loss-offunction mutation in the FasL gene (Takahashi et al., 1994) were protected partially against apoptosis.

Apoptosis of adult MNs occurs over a period of days, yet apoptosis through Fas is typically rapid and independent of new RNA or protein synthesis (Nagata, 1999). Variations of this mechanism could be operative in injured adult MNs, because Fas-mediated death of MNs in vitro can involve transcriptional upregulation, notably for nNOS (Raoul et al., 2002), and might depend on the level of FLIP (FLICE inhibitory protein), the binding of which to Fas competes with activation of caspase-8 (Walsh et al., 2003). Moreover, p53 activation regulates the sensitivity to apoptosis by allowing cytoplasmic Fas to redistribute to the cell surface (Bennett et al., 1998), this finding would be consistent with the rich cytoplasmic localization of Fas in wt MNs. Another possibility for delay is p53 transactivation. The Fas gene promoter contains a p53-responsive element, and wt p53 can bind 
and activate Fas gene transcription (Müller et al., 1998). The delayed Fas protein upregulation seen at 5-7 d in wt MNs after SNA is consistent with this idea. We show that mice deficient in p53 do not upregulate Fas. Thus, Fas regulation of adult MN apoptosis is downstream to p53 activation. The role of $\mathrm{p} 53$ in $\mathrm{MN}$ apoptosis is strengthened by work showing that Noxa, another p53 target gene, is a mediator of $\mathrm{MN}$ death in the adult mouse brainstem (Kiryu-Seo et al., 2005).

We found that normal adult MNs express constitutively both nNOS and iNOS. Previous studies have indicated that nNOS and NADPH diaphorase are not expressed in normal adult MNs (Wu, 1993), although more recent reports show expression (Zhou et al., 1999; Keilhoff et al., 2004). The presence of nNOS and iNOS in normal MNs was confirmed using several antibodies with confirmed specificities. Interestingly, iNOS is the source of most of the constitutive NOS activity (NADPH diaphorase) in MNs, with nNOS being present but seemingly inactive enzymatically. Endogenous protein inhibitors of nNOS and dimerization state could be responsible for the catalytic inactivation (Kone et al., 2003).

Our experiments show that NOS regulates adult $\mathrm{MN}$ apoptosis. The different NOS isoforms changed reciprocally during MN apoptosis; nNOS protein was upregulated, whereas iNOS protein was downregulated. But, the residual iNOS contributes more than the upregulated nNOS to the injury-induced transient increase in NADPH diaphorase activity and NO production seen at 4-7 d after SNA. Mice deficient in either nNOS or iNOS escaped injury-induced apoptosis. However, the $\mathrm{nNOS}^{-1-}$ mice still have low levels of two alternative nNOS isoforms (Faccchnetti et al., 1999). Both $i$ NOS and $n N O S$ gene deletion abrogated the DNA damage in MNs. Because iNOS is the source of most of the injury-induced NOS activity (NADPH diaphorase) in MNs, deletion of iNOS is likely to be protective through attenuating the formation of DNA damage. nNOS deletion could be protective through different mechanisms, specifically enhancement of DNA repair, as supported by the constitutive upregulation of Ogg1 protein and activity in $\mathrm{nNOS}^{-1-}$ mice. NO blocks DNA repair by inhibiting Ogg1 (Jaiswal et al., 2001) and poly(ADPribose) polymerase (Sidorkina et al., 2003); thus, nNOS upregulation after SNA might function to inhibit DNA repair as part of the apoptotic program. The lack of nNOS induction in MNs in mSOD1 with
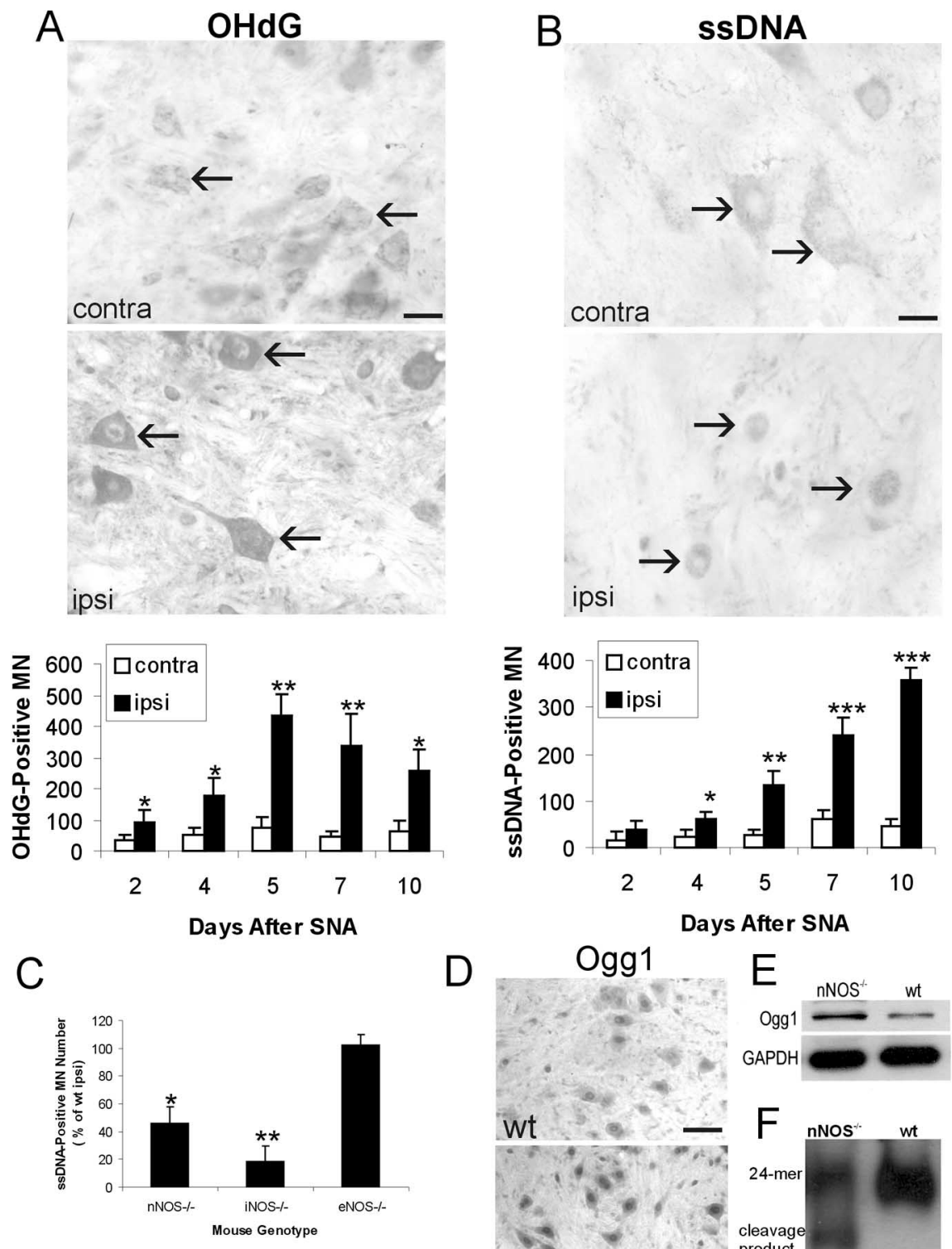

D

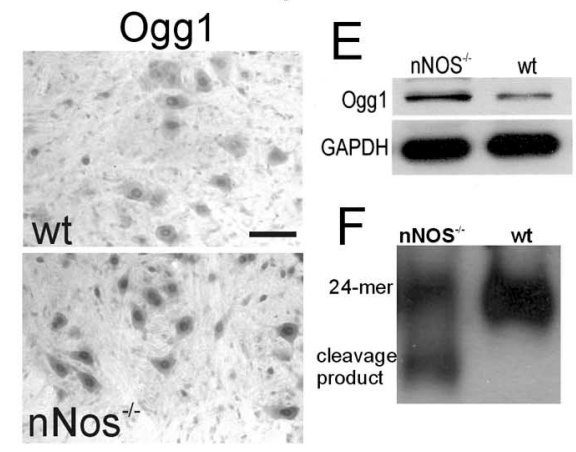

Figure 5. Identification of DNA damage in MNs after SNA. Spinal cord sections were reacted with monoclonal antibodies to OHdG $(\boldsymbol{A})$ and ssDNA $(\boldsymbol{B})$ with sites of antibody binding visualized by immunoperoxidase and DAB (dark reaction product). Sections exposed to the same antibody were processed using identical conditions. These examples are from rats at $4 \mathrm{~d}(\mathrm{OHdG})$ or $5 \mathrm{~d}$ (ssDNA) after lesion. $\boldsymbol{A}, 0 H d G$ IR in ipsilateral MNs (arrows) was elevated compared with contralateral nonlesioned MNs. Subsets of ipsilateral MNs (see bottom panel for quantification) had intense cytoplasmic and nuclear OHdG IR (asterisks), whereas contralateral MNs had mostly cytoplasmic $0 \mathrm{HdG}$ IR. The graph shows counts of the numbers of $0 \mathrm{HdG}{ }^{+}$MNs in the ipsilateral (filled bars) and contralateral (open bars) lumbar spinal cord at 2, 4,5,7, and $10 \mathrm{~d}$ after SNA ( $n=6$ rats per time point). Cells with only nuclear IR were counted. The values are mean \pm SD. ${ }^{*} p<0.05,{ }^{* *} p<0.01$, significant differences from contralateral MNs. B, ssDNA IR in the nucleus of ipsilateral MNs (arrows) was augmented compared with the faint labeling in contralateral MNs. Subsets of ipsilateral MNs had nuclear ssDNA IR (asterisks), whereas contralateral MNs had infrequent nuclear labeling. The graph shows counts of the numbers of ssDNA ${ }^{+}$MNs in the ipsilateral (filled bars) and contralateral (open bars) lumbar spinal cord at 2, 4, 5,7, and $10 \mathrm{~d}$ after SNA ( $n=6$ rats per time point). Cells with nuclear IR were counted. The values are mean \pm SD. $\left.{ }^{*} p<0.05\right)$, ${ }^{* *} p<$ $0.01),{ }^{* * *} p<0.001$, significant differences from contralateral MNs. C, Counts of ssDNA ${ }^{+}$MNs at $7 \mathrm{~d}$ after SNA in NOS-deficient mice. ${ }^{*} p<0.05,{ }^{* *} p<0.01$, significance differences from counts of ipsilateral MNs in corresponding wt control mice. Mice with nNOS and iNOS had significantly attenuated DNA damage. $\boldsymbol{D}$, Constitutive levels of $0 \mathrm{gg} 1$ were upregulated in nNOS ${ }^{-1-}$ mice. Immunohistochemistry shows that MNs in $\mathrm{nNOS}^{-1-}$ mice are robustly immunopositive for $0 \mathrm{gg} 1$ compared with MNs in wt mice. $\boldsymbol{E}$, Western blots of the lumbar spinal cord ventral horn confirmed the upregulation of $0 \mathrm{gg} 1$ in nNOS ${ }^{-/-}$mice. GAPDH was a loading control. $\boldsymbol{F}$, Biochemical activity assay, as determined by cleavage of a 24-mer oligonucleotide containing 8-0x0G (40 $\mu \mathrm{g}$ of nuclear protein was reacted in each lane) revealed increased $0 \mathrm{gg} 1$ activity in nNOS ${ }^{-1-}$ mouse CNS tissue. Under these reaction conditions, enzyme activity in wt mice was undetectable. Scale bars: $\boldsymbol{A}, 40 \mu \mathrm{m} ; \boldsymbol{B}, 37 \mu \mathrm{m} ; \boldsymbol{D}, 87 \mu \mathrm{m}$. ipsi, Ipsilateral; contra, contralateral. 


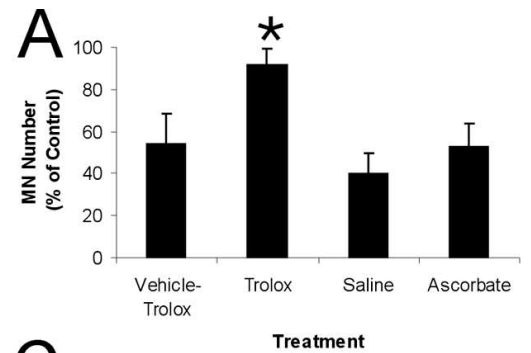

B
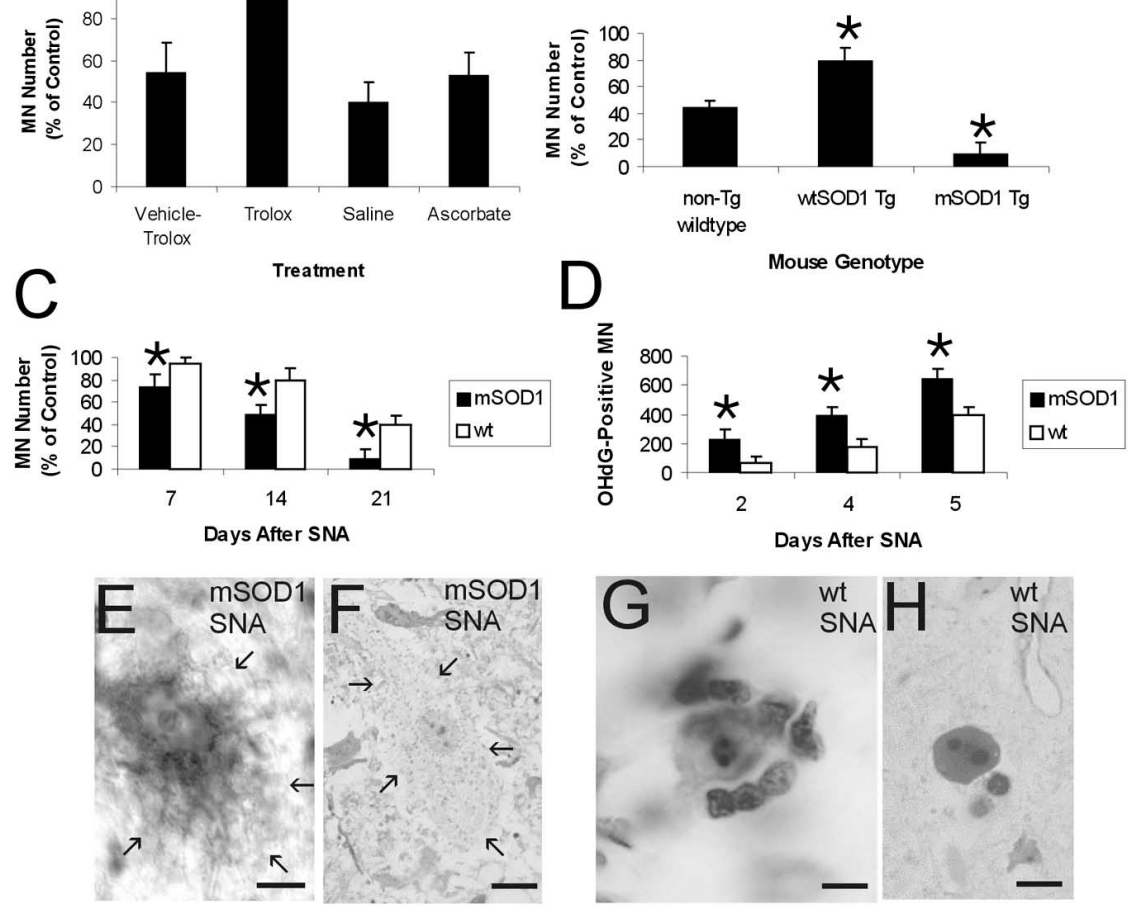

I
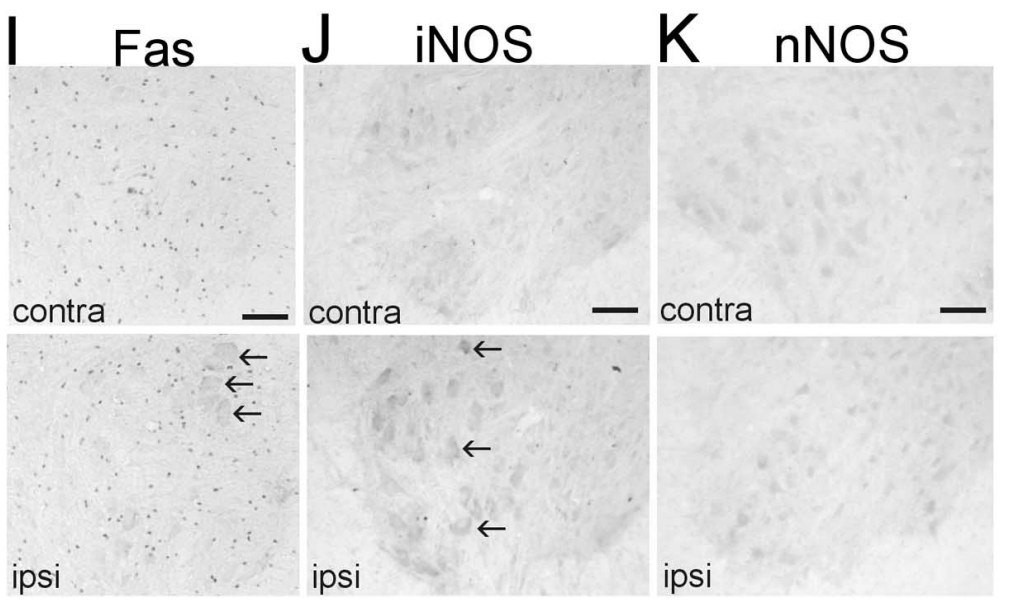

Figure 6. Modulation of MN responses after SNA with antioxidant pharmacotherapy and SOD1 transgenesis. $\boldsymbol{A}$, Rats were exposed to different drug treatment regimens starting $3 \mathrm{~d}$ before lesion and continuing through $21 \mathrm{~d}$ after SNA and were killed for stereological counting of lumbar MNs. Trolox (a vitamin E derivative) protected MNs against apoptosis. Ascorbate afforded no protection. The values are mean \pm SD. ${ }^{*} p<0.05$, significant difference from vehicle control. $\boldsymbol{B}$, SOD1 is a modifier gene for MN apoptosis. Non-tg wt mice and tg mice overexpressing wt human S0D1 (wtSOD1 tg) or mutant human S0D1 (mS0D1, G93A) received a unilateral SNA and were killed at $21 \mathrm{~d}$ after lesion. MN loss was attenuated by wt SOD1 and was worsened by mSOD1. The values are mean \pm SD. ${ }^{*} p<0.05$, significant difference from wt non-tg control. C, mSOD1 accelerates MN loss after SNA. Non-tg wt mice and tg mice overexpressing mutant human S0D1 (mSOD1, G93A) received a unilateral SNA and were killed at 7 , 14 , and $21 \mathrm{~d}$ after lesion. Loss of MNs occurred weeks sooner in mSOD1 mice compared with wt controls. The values are mean \pm SD. ${ }^{*} p<0.05$, significant difference from time-matched wt non-tg control. D, mSOD1 accelerates and escalates DNA damage in MNs after SNA. Non-tg wt mice and tg mice overexpressing mutant human S0D1 (mSOD1, G93A) received a unilateral SNA and were killed at 2, 4, and 5 d after lesion. Ipsilateral MNs with $0 \mathrm{HdG}$ nuclear staining were counted. The values are mean \pm SD. ${ }^{*} p<$ 0.05 , significant difference from time-matched wt non-tg control. $\boldsymbol{E}-\boldsymbol{H}, \mathrm{mSOD1}$ changes the structural phenotype of the MN degeneration induced by SNA from apoptosis to necrosis. Nissl staining shows the MN swelling and cytoplasmic vacuolation (E, arrows) in mSOD1 MNs, with confirmation of the cytoplasmic dissolution confirmed in $1 \mu \mathrm{m}$ plastic sections ( $\boldsymbol{F}$, arrows). In contrast, Nissl staining of lesioned MNs in wt shows the apoptosis as characterized by cell shrinkage and chromatin aggregation $(\boldsymbol{G})$, with confirmation of the cytoplasmic and nuclear condensation seen in $1 \mu \mathrm{m}$ plastic sections $(\boldsymbol{H})$. I, Immunolocalization of Fas in MSOD1 mice shows elevated IR in ipsilateral MNs (arrows) compared with nonlesioned contralateral MNs in the lumbar spinal cord at $5 \mathrm{~d}$ after SNA. Immunopositive small dots are microglia or related cells. J, Immunolocalization of iNOS shows that constitutive levels of iNOS are low in presymptomatic mSOD1 mice and that iNOS IR is elevated in ipsilateral MNs (arrows) compared with nonlesioned contralateral MNs in the lumbar spinal cord at $5 \mathrm{~d}$ after SNA. $\boldsymbol{K}$, Immunolocalization of nNOS shows that constitutive levels of $n N O S$ are low in MNs in presymptomatic mSOD1 mice (contralateral) and that nNOS levels remain low in MNs after SNA (ipsilateral). Scale bars: $\boldsymbol{E}, 10 \mu \mathrm{m} ; \boldsymbol{F}, 20 \mu \mathrm{m} ; \boldsymbol{G}, 10 \mu \mathrm{m} ; \boldsymbol{H}, 20 \mu \mathrm{m} ; \boldsymbol{I}-\boldsymbol{K}, 410 \mu \mathrm{m}$.
SNA is consistent with this idea because the $\mathrm{MN}$ death was not apoptotic.

Our results implicate $\mathrm{ONOO}^{-}$in the mechanisms of adult MN apoptosis. $\mathrm{ONOO}^{-}$is a strong oxidant formed by a diffusion-limited reaction between $\mathrm{NO}$ and superoxide anion (Beckman et al., 1992). Both $\mathrm{NO}$ and $\mathrm{ONOO}^{-}$accumulated transiently in MNs destined for apoptosis. Superoxide anion production in MNs was not tracked here; however, in related studies, axotomized MNs accumulate large numbers of active mitochondria in their cell bodies (Martin et al., 1999) and can generate high amounts of superoxide (Liu and Martin, 2001). Injured MNs accumulated 3-nitrotyrosine IR, indicating the presence of $\mathrm{ONOO}^{-}$. Trolox, an antioxidant with $\mathrm{ONOO}^{-}$scavenging activity (Salgo and Pryor, 1996), protected MNs from apoptosis. However, it is still not definite that $\mathrm{ONOO}^{-}$is killing the MNs. Another mediator of toxicity could be the hydroxy radical $(\cdot \mathrm{OH})$. $\mathrm{ONOO}^{-}$ can homolyze after protonation to generate $\cdot \mathrm{OH}$ (Coddington et al., 1998), but this reaction has been questioned (Kissner et al., 2003). The increased OHdG staining in injured MNs is consistent with the formation of $\cdot \mathrm{OH}$.

The work on SOD1 mice also supports the roles for $\mathrm{ONOO}^{-}$and $\cdot \mathrm{OH}$ in the mechanisms of adult MN degeneration. Overexpression of wt human SOD1 protected MNs from apoptosis. In contrast, SNA in $\mathrm{MSOD} 1$ mice, at a time long before the clinical emergence of disease, caused $\mathrm{MN}$ degeneration with an accelerated rate and greater severity compared with wt mice. Moreover, mSOD1 amplified the OHdG-DNA damage and shifted the cellular pathology from apoptosis to a necroticlike death. Thus, mSOD1 exacerbates MN responses to injury. This exacerbation seems to be mediated by iNOS because it was upregulated, in contrast to the downregulation seen in wt mice. $\mathrm{ONOO}^{-}$or $\cdot \mathrm{OH}$ might mediate the spontaneous $\mathrm{MN}$ degeneration in mSOD1 mice (Beckman et al., 2001; Liu et al., 1999), but this issue is controversial (Bruijin et al., 2004). Moreover, $\mathrm{ONOO}^{-}$ has a role in the potentiation of Fas-induced MN degeneration (Raoul et al., 2002). Our results support a potential role for $\mathrm{ONOO}^{-}$ as a common mechanism in injury-induced death of adult wt MNs and MNs harboring mSOD1.

DNA damage could be an upstream trigger for $\mathrm{MN}$ apoptosis. MNs acquired two forms of DNA damage at early preapoptotic stages, observed as OHdG-DNA lesions and ssDNA lesions. Several reactive oxygen species, including $\mathrm{H}_{2} \mathrm{O}_{2}, \cdot \mathrm{OH}$, and 
$\mathrm{ONOO}^{-}$, induce DNA damage (Aust and Eveleigh, 1999). The precursors of $\mathrm{ONOO}^{-}$, $\mathrm{NO}$ and superoxide anion (Beckman, 1990), by themselves are not aggressively genotoxic. The MN genome is particularly sensitive to $\mathrm{ONOO}^{-}$; it induces abasic sites, single-strand breaks, and double-strand breaks (Martin and Liu, 2002b). $\mathrm{ONOO}^{-}$can also cause OHdG lesions through the formation of $\cdot \mathrm{OH}$-like intermediates (Coddington et al., 1998). OHdG-DNA and ssDNA lesions in injured MNs could be related, because OH-DNA adducts can lead to abasic sites that are converted to DNA single-strand breaks (Kohn, 1991). The formation of ssDNA in preapoptotic MNs is consistent with a p53dependent, Fas-regulated cell death mechanism.

\section{References}

Al-Abdulla NA, Martin LJ (1998) Apoptosis of retrogradely degenerating neurons occurs in association with the accumulation of perikaryal mitochondria and oxidative damage to the nucleus. Am J Pathol 153:447-456.

Almer G, Vukosavic S, Romero N, Przedborski S (1999) Inducible nitric oxide synthase up-regulation in a transgenic mouse model of familial amyotrophic lateral sclerosis. J Neurochem 72:2415-2425.

Aust AE, Eveleigh JF (1999) Mechanisms of DNA oxidation. Proc Soc Exp Biol Med 222:246-252.

Barbeito LH, Pehar M, Cassina P, Vargas MR, Peluffo H, Viera L, Estévez AG, Beckman JS (2004) A role for astrocytes in motor neuron loss in amyotrophic lateral sclerosis. Brain Res Brain Res Rev 47:263-274.

Beckman JS (1990) Ischaemic injury mediator. Nature 345:27-28.

Beckman JS, Chen J, Ischiropoulos H, Conger KA (1992) Inhibition of nitric oxide synthesis and cerebral protection. In: Pharmacology of cerebral ischemia (Krieglstein J, Oberpichler-Schwenk H, eds), pp 383-394. Stuttgart: Wissenschaftliche Verlagsgesellschaft.

Beckman JS, Carson M, Smith CD, Koppenol WH (1993) ALS, SOD and peroxynitrite. Nature 364:548.

Beckman JS, Estévez AG, Crow JP, Barbeito L (2001) Superoxide dismutase and the death of motoneurons in ALS. Trends Neurosci 24:S15-S20.

Bennett M, Macdonald K, Chan SW, Luzio JP, Simari R, Weissberg P (1998) Cell surface trafficking of fas: a rapid mechanism of p53-mediated apoptosis. Science 282:290-293.

Boiteux S, Radicella JP (2000) The human OGG1 gene: structure, functions, and its implications in the process of carcinogenesis. Arch Biochem Biophys 377:1-8.

Bruijn LI, Miller TM, Cleveland DW (2004) Unraveling the mechanisms involved in motor neuron degeneration in ALS. Annu Rev Neurosci 27:723-749

Calhoun ME, Jucker M, Martin LJ, Thinakaran G, Price DL, Mouton PR (1996) Comparative evaluation of synaptophysin-based methods for quantification of synapses. J Neurocytol 25:821-828.

Carr A, Frei B (1999) Does vitamin C act as a pro-oxidant under physiological conditions? FASEB J 13:1007-1024.

Catania MV, Aronica E, Yankaya B, Troost D (2001) Increased expression of neuronal nitric oxide synthase spliced variants in reactive astrocytes of amyotrophic lateral sclerosis human spinal cord. J Neurosci 21:RC148(1-5).

Chen X, Sheng C, Zheng X (2001) Direct nitric oxide imaging in cultured hippocampal neurons with diaminoanthraquione and confocal microscopy. Cell Biol Int 25:593-598.

Christmann M, Tomicic MT, Roos WP, Kaina B (2003) Mechanisms of human DNA repair: an update. Toxicology 193:3-34.

Coddington JW, Hurst JK, Lymar SV (1998) Hydroxyl radical formation during peroxynitrous acid decomposition. J Am Chem Soc 121:2438-2443.

Danial NN, Korsmeyer SJ (2004) Cell death: critical control points. Cell 116:205-219.

Deng H-X, Hentati A, Tainer JA, Iqbal Z, Cayabyab A, Hung W-Y, Getzoff ED, Hu P, Herzfeldt B, Roos RP, Warner C, Deng G, Soriano E, Smyth C, Parge HE, Ahmed A, Roses AD, Hallewell RA, Pericak-Vance MA, Siddique T (1993) Amyotrophic lateral sclerosis and structural defects in $\mathrm{Cu}, \mathrm{Zn}$ superoxide dismutase. Science 261:1047-1051.

Desbarats J, Birge RB, Mimouni-Rongy M, Weinstein DE, Palerme JS, Newell MK (2003) Fas engagement induces neurite growth through ERK activation and p35 upregulation. Nat Cell Biol 5:118-125.
Estévez AG, Jordán J (2002) Nitric oxide and superoxide, a deadly cocktail. Ann NY Acad Sci 962:207-211.

Estévez AG, Spear N, Manuel SM, Radi R, Henderson CE, Barbeito L, Beckman JS (1998) Nitric oxide and superoxide contribute to motor neuron apoptosis induced by trophic factor deprivation. J Neurosci 18:923-931.

Estévez AG, Crow JP, Sampson JB, Reiter C, Zhuang Y, Richardson GJ, Tarpey MM, Barbeito L, Beckman JS (1999) Induction of nitric oxidedependent apoptosis in motor neurons by zinc-deficient superoxide dismutase. Science 286:2498-2500.

Facchinetti F, Sasaki M, Cutting FB, Zhai P, MacDonald JE, Reif D, Beal MF, Huang PL, Dawson TM, Gurney ME, Dawson VL (1999) Lack of involvement of neuronal nitric oxide synthase in the pathogenesis of a transgenic mouse model of familial amyotrophic lateral sclerosis. Neuroscience 90:1483-1492.

Ferrante RJ, Browne SE, Shinobu LA, Bowling AC, Baik MJ, MacGarvey U, Kowall NW, Brown Jr RH, Beal MF (1997) Evidence of increased oxidative damage in both sporadic and familial amyotrophic lateral sclerosis. J Neurochem 69:2064-2074.

Frankfurt OS, Robb JA, Sugarbaker EV, Villa L (1996) Monoclonal antibody to single-stranded DNA is a specific and sensitive cellular marker for apoptosis. Exp Cell Res 226:387-397.

Glücksmann A (1951) Cell deaths in normal vertebrate ontogeny. Biol Rev 26:59-86.

Graham EM, Sheldon RA, Flock DL, Ferriero DM, Martin LJ, O’Riordan DP, Northington FJ (2004) (2004) Neonatal mice lacking functional Fas death receptors are resistant to hypoxic-ischemic brain injury. Neurobiol Dis 17:89-98.

Greenlund LJ, Deckwerth TL, Johnson Jr EM (1995) Superoxide dismutase delays neuronal apoptosis: a role for reactive oxygen species in programmed neuronal death. Neuron 14:303-315.

Gurney ME, Pu H, Chiu AY, Dal Canto MC, Polchow CY, Alexander DD, Caliendo J, Hentati A, Kwon YW, Deng HX, Chen W, Zhai P, Sufit RL, Siddique T (1994) Motor neuron degeneration in mice that express a human $\mathrm{Cu}, \mathrm{Zn}$ superoxide dismutase mutation. Science 264:1772-1775.

Heiduschka P, Thanos S (1998) NO production during neuronal cell death can be directly assessed by a chemical reaction in vivo. NeuroReport 9:4051-4057.

Hollenbach S, Dhénaut A, Eckert I, Radicella JP, Epe B (1999) Overexpression of Ogg1 in mammalian cells: effects on induced and spontaneous oxidative DNA damage and mutagenesis. Carcinogenesis 20:1863-1868.

Hope BT, Michael GJ, Knigge KM, Vincent SR (1991) Neuronal NADPH diaphorase is a nitric oxide synthase. Proc Natl Acad Sci USA 88:2811-2814.

Jaiswal M, LaRusso NF, Nishioka N, Nakabeppu Y, Gores GJ (2001) Human Ogg1, a protein involved in the repair of 8-oxoguanine, is inhibited by nitric oxide. Cancer Res 61:6388-6393.

Jayaraman L, Prives C (1995) Activation of p53 sequence-specific DNA binding by short single strands of DNA requires the p53 C-terminus. Cell 81:1021-1029.

Keilhoff G, Fansa H, Wolf G (2004) Neuronal NOS deficiency promotes apoptotic cell death of spinal cord neurons after peripheral nerve transection. Nitric Oxide 10:101-111.

Kiryu-Seo S, Hirayama T, Kato R, Kiyama H (2005) Noxa is a critical mediator of p53-dependent motor neuron death after nerve injury in adult mouse. J Neurosci 25:1442-1447.

Kissner R, Nauser T, Kurz C, Koppenol WH (2003) Peroxynitrous acidwhere is the hydroxyl radical? IUMBM Life 55:567-572.

Kohn KW (1991) Principles and practice of DNA filter elution. Pharmacol Ther 49:55-77.

Kone BC, Kuncewicz T, Zhang W, Yu ZY (2003) Protein interactions with nitric oxide synthases: controlling the right time, the right place, and the right amount of nitric oxide. Am J Physiol Renal Physiol 285:F178-F190.

Lesuisse C, Martin LJ (2002) Immature and mature neurons engage different apoptotic mechanisms involving caspase- 3 and the mitogen-activated protein kinase pathway. J Cereb Blood Flow Metab 22:935-950.

Liu D, Wen J, Liu J, Li L (1999) The roles of free radicals in amyotrophic lateral sclerosis: reactive oxygen species and elevated oxidation of protein, DNA, and membrane phospholipids. FASEB J 13:2318-2328.

Liu Z, Martin LJ (2001) Motor neurons rapidly accumulate DNA singlestrand breaks after in vitro exposure to nitric oxide and peroxynitrite and in vivo axotomy. J Comp Neurol 432:35-60.

Lok J, Martin LJ (2002) Rapid subcellular redistribution of Bax precedes 
caspase- 3 and endonuclease activation during excitotoxic neuronal apoptosis in rat brain. J Neurotrauma 19:815-828.

Martin LJ (1999) Neuronal death in amyotrophic lateral sclerosis is apoptosis: possible contribution of a programmed cell death mechanism. J Neuropathol Exp Neurol 58:459-471.

Martin LJ (2000) p53 is abnormally elevated and active in the CNS of patients with amyotrophic lateral sclerosis. Neurobiol Dis 7:613-622. 40:185-201.

Martin LJ, Liu Z (2002a) Injury-induced spinal motor neuron apoptosis is preceded by DNA single-strand breaks and is p53- and bax-dependent. J Neurobiol 5:181-197.

Martin LJ, Liu Z (2002b) DNA damage profiling in motor neurons: a singlecell analysis by comet assay. Neurochem Res 27:1089-1100.

Martin LJ, Kaiser A, Price AC (1999) Motor neuron degeneration after sciatic nerve avulsion in adult rat evolves with oxidative stress and is apoptosis. J Neurobiol

Martin LJ, Kaiser A, Yu JW, Natale JE, Al-Abdulla NA (2001) Injury-induced apoptosis of neurons in adult brain is mediated by p53-dependent and p53-independent pathways and requires Bax. J Comp Neurol 433:299-311.

Mattson MP, Duan W, Chan SL, Camandola S (1999) Par-4. An emerging pivotal player in neuronal apoptosis and neurodegenerative disorders. J Mol Neurosci 13:17-30.

McClendon KB, Martin LJ (2003) Damage to genomic DNA is increased in individuals with amyotrophic lateral sclerosis. Soc Neurosci Abstr 29:450.11.

Müller M, Wilder S, Bannasch D, Israeli D, Lehlbach K, Li-Weber M, Friedman SL, Galle PR, Stremmel W, Oren M, Krammer PH (1998) p53 activates the CD95 (APO-1/Fas) gene in response to DNA damage by anticancer drugs. J Exp Med 188:2033-2045.

Nagata S (1999) Fas ligand-induced apoptosis. Annu Rev Genet 33:29-55.

Northington FJ, Koehler RC, Traystman RJ, Martin LJ (1996) Nitric oxide synthase 1 and nitric oxide synthase 3 protein expression is regionally and temporally regulated in fetal brain. Dev Brain Res 95:1-14.

Oppenheim RW (1991) Cell death during development of the nervous system. Annu Rev Neurosci 14:453-501.

Raivich G, Liu ZQ, Kloss CUA, Labow M, Bluethmann H, Bohatschek M (2002) Cytotoxic potential of proinflammatory cytokines: combined deletion of TNF receptors TNFR1 and TNFR2 prevents motoneuron cell death after facial axotomy in adult mouse. Exp Neurol 178:186-193.

Raoul C, Henderson CE, Pettmann B (1999) Programmed cell death of embryonic motoneurons triggered through the Fas death receptor. J Cell Biol 147:1049-1061.

Raoul C, Estévez AG, Nishimune H, Cleveland DW, deLapeyrière O, Henderson CE, Haase G, Pettmann B (2002) Motoneuron death triggered by a specific pathway downstream of Fas: potentiation by ALS-linked SOD1 mutations. Neuron 35:1067-1083.

Reaume AG, Elliott JL, Hoffman EK, Kowall NW, Ferrante RJ, Siwek DF, Wilcox HM, Flood DG, Beal MF, Brown Jr RH, Scott RW, Snider WD (1996) Motor neurons in Cu/Zn superoxide dismutase-deficient mice develop normally but exhibit enhanced cell death after axonal injury. Nat Genet 13:43-47.

Reiter CD, Teng RJ, Beckman JS (2000) Superoxide reacts with nitric oxide to nitrate tyrosine at physiological $\mathrm{pH}$ via peroxynitrite. J Biol Chem 275:32460-32466.

Rich T, Allen RL, Wyllie AH (2000) Defying death after DNA damage. Nature 407:777-783.
Rosen DR, Siddique T, Patterson D, Figiewicz DA, Sapp P, Hentati A, Donalsson D, Goto J, O’Regan JP, Deng H-X, Rahmani Z, Krizus A, McKennaYasek D, Cayabyab A, Gaston AM, Berger R, Tanzi RE, Halperin JJ, Harzfeldt B, Van den Bergh R, et al. (1993) Mutations in Cu/Zn superoxide dismutase gene are associated with familial amyotrophic lateral sclerosis. Nature 362:59-62.

Salgo MG, Pryor WA (1996) Trolox inhibits peroxynitrite-mediated oxidative stress and apoptosis in rat thymocytes. Arch Biochem Biophys 333:482-488.

Sasaki S, Shibata N, Komori T, Iwata M (2000) iNOS and nitrotyrosine immunoreactivity in amyotrophic lateral sclerosis. Neurosci Let 291:44-48.

Sathasivam S, Ince PG, Shaw PJ (2001) Apoptosis in amyotrophic lateral sclerosis: a review of the evidence. Neuropathol Appl Neurobiol 27:257-274.

Shaikh AY, Martin LJ (2002) DNA base-excision repair enzyme apurinic/ apyrimidinic endonuclease/redox factor- 1 is increased and competent in brain and spinal cord of individuals with amyotrophic lateral sclerosis. Neuromol Med 2:47-60.

Sidorkina O, Espey MG, Miranda KM, Wink DA, Laval J (2003) Inhibition of poly(ADP-ribose) polymerase (PARP) by nitric oxide and reactive nitrogen oxide species. Free Radic Biol Med 35:1431-1438.

Son M, Fathallah-Shaykh HM, Elliott JL (2001) Survival in a transgenic model of FALS is independent of iNOS expression. Ann Neurol 50:273.

Takahashi T, Tanaka M, Brannan CI, Jenkins NA, Copeland NG, Suda T, Nagata S (1994) Generalized lymphoproliferative disease in mice caused by a point mutation in the Fas ligand. Cell 76:969-976.

Ugolini G, Raoul C, Ferri A, Haenggeli C, Yamamoto Y, Salaün D, Henderson CE, Kato AC, Pettmann B, Hueber A (2003) Fas/tumor necrosis factor receptor death signaling is required for axotomy-induced death of motoneurons in vivo. J Neurosci 23:8526-8531.

Usuki F, Yasutake A, Umehara F, Tokunaga H, Matsumoto M, Eto K, Ishiura $S$, Higuchi I (2001) In vivo protection of a water-soluble derivative of vitamin E, Trolox, against methylmercury-intoxication in the rat. Neurosci Lett 304:199-203.

Von Bohlen und Halbach O, Albrecht D, Heinemann U, Schuchmann S (2002) Spatial nitric oxide imaging using 1,2-diaminoanthraquione to investigate the involvement of nitric oxide in long-term potentiation in rat brain slices. NeuroImage 15:633-639.

Waldmeier PC (2003) Prospects for antiapoptotic drug therapy of neurodegenerative diseases. Prog Neuro-Psychopharmacol Biol Psychiatry 27:303-321.

Walsh CM, Luhrs KA, Arechiga AF (2003) The "fuzzy logic" of the deathinducing signaling complex in lymphocytes. J Clin Immunol 23:333-353.

Wu W (1993) Expression of nitric-oxide synthase (NOS) in injured CNS neurons as shown by NADPH diaphorase histochemistry. Exp Neurol 120:153-159.

Wu W, Li L (1993) Inhibition of nitric oxide synthase reduces motorneuron death due to spinal root avulsion. Neurosci Lett 153:121-124.

Wu W, Li L, Yick LW, Chai H, Xie Y, Yang Y, Prevette DM, Oppenheim RW (2003) GDNF and BDNF alter the expression of neuronal NOS, c-Jun, and p75 and prevent motoneuron death following spinal root avulsion in adult rats. J Neurotrauma 20:603-612.

Zhou Y, Zhao YN, Yang EB, Ling EA, Wang Y, Hassouna MM, Mack P (1999) Induction of neuronal and inducible nitric oxide synthase in the motoneurons of spinal cord following transient abdominal aorta occlusion in rats. J Surg Res 87:185-193. 